\title{
"الذات" في أدب إقبال \\ مفهومها، ومعالم بنائها، ودورها في النهوض الحضاري للأمة
}

* محمد أعظم الندوي

$$
\begin{aligned}
& \text { الملخص } \\
& \text { تعالج هذه الورقة موضوع الذات في كتابات إقبال: من حيث مفهومها، ومعالم بنائها، ودورها في النـــهوض }
\end{aligned}
$$

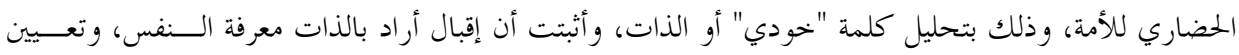

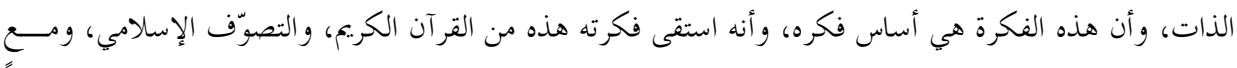

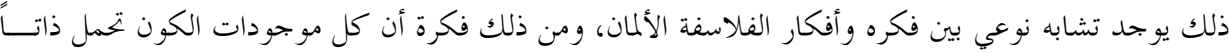

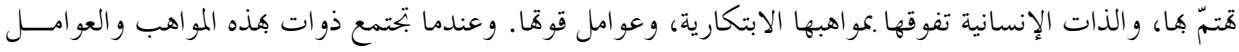

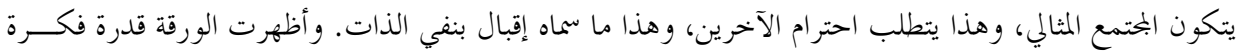

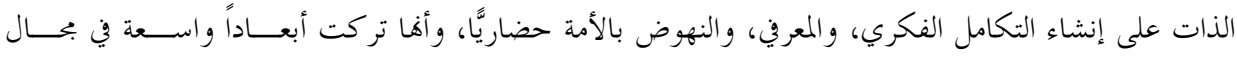

$$
\begin{aligned}
& \text { الإصلاح، والتجديد الفكري. } \\
& \text { الكلمات المفتاحية: محمد إقبال، الذات، نفي الذات، التجديد الفكري، النهوض الحضاري. }
\end{aligned}
$$

\section{"Self" in Iqbal Literature:}

\section{Its Concept, Building Features, and Role in Cultural Advancement of the Umma Abstract}

This paper investigates the topic of "Self or Ego" in Iqbal's writings: its concept, building features, and its role in the Umma cultural advancement, through analyzing the term $k$ hod $i=$ self or ego. When Iqbal talks about self, he means self-knowledge and self-identification. The "self" idea is the basis of Iqbal's thought, were he drew it from the Holy Quran and Islamic Sufism. However we may find a similarity between his thought and thoughts and ideas of German philosophers, especially his idea that all existing things in the universe have an "ego" to care about, and human ego has a superiority due to its innovative talents ant to factors that increase its strength. When egos with such specifications meet, an ideal society is made up. This requires respect for others, and the demand to deny oneself. The paper shows the ability of the ego idea to create intellectual and epistemological integration, to help the Umman to achieve cultural advancement and to provide wide horizons in the field of reform and intellectual renewal.

Keywords: Muhammad Iqbal, Self (ego), Self-denial, intellectual renewal, Cultural advancement.

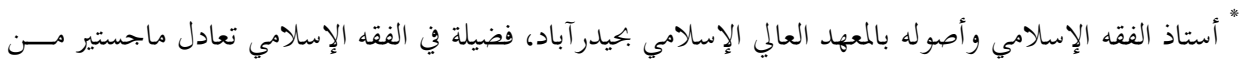

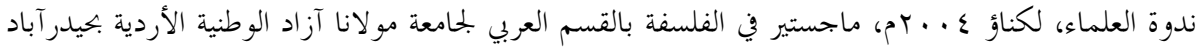

$$
\begin{aligned}
& \text { mohdazamnadwi@gmail.com : } 17
\end{aligned}
$$

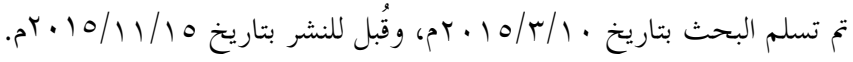




\section{مقدمة:}

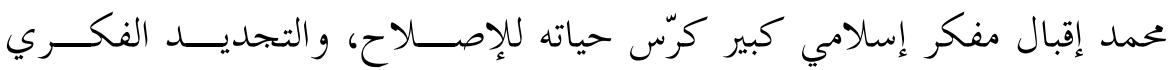

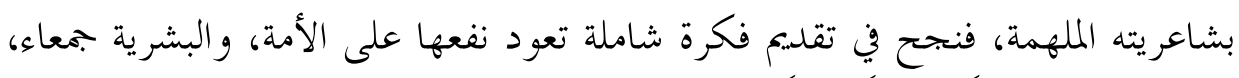

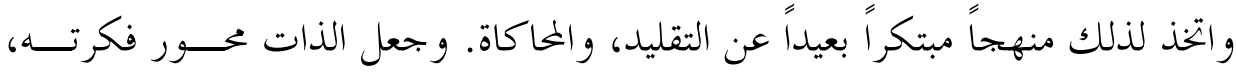

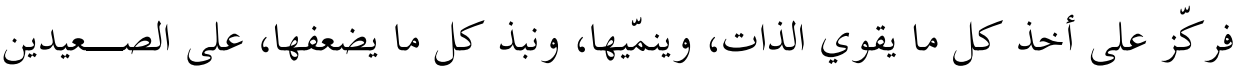

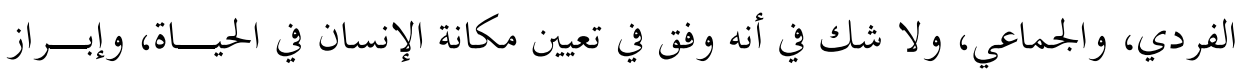

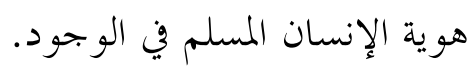

و يكتسب هذا البحث أهميته من خلال النقاط الآتية:

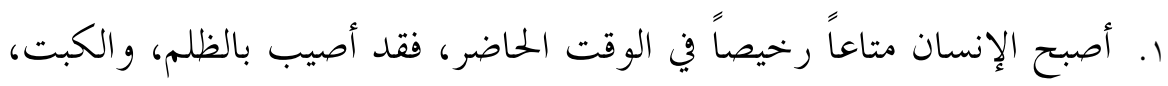

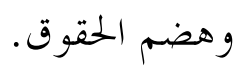

r. وقع المسلم المعاصر في حيرة، وقلق، وغدا يشك في إمكانياته، وصلاحياته لما

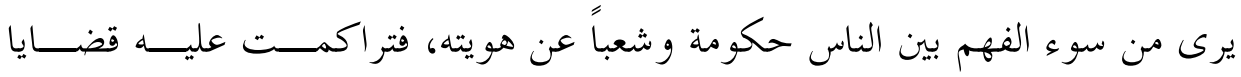
حضارية، و سياسية تؤرقه، و تصيبه بمر كب النقص، و والهو ان.

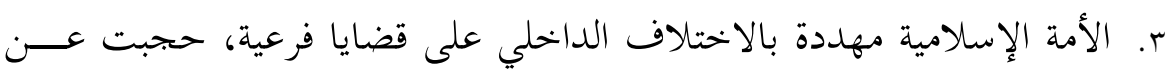

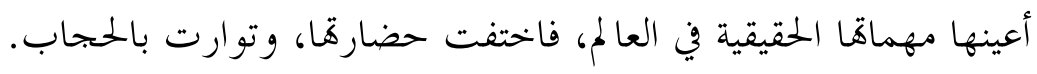

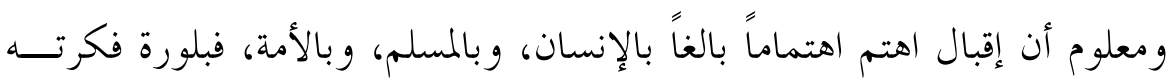
عن الذات سوف تعيد الثقة فيهم. ويمكن صو غ أهداف البحث فيما يأتي:

1. تعيين مفهوم الذات عند إقبال، و الكشف عن معالم بنائها، وبتحلياها.

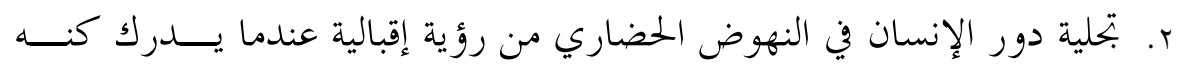
حقيقة ذاته.

r. الكشف عن جوانب الإصلاح و التجديد مما له صلة بالذات في فكر إقبال.

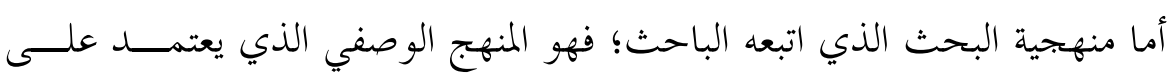

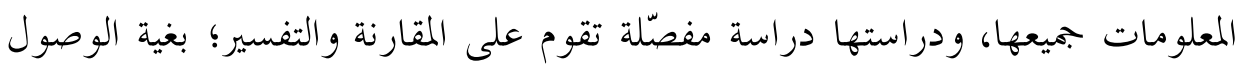

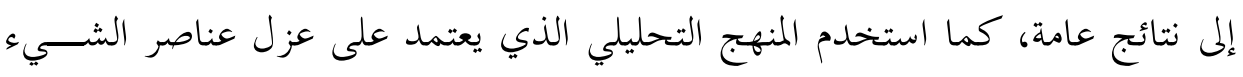


الواحد بعضها عن بعض، ودراسة هذه العناصر دراسة جزئية، وإدراك الصلة الرابطـــة

بينها.

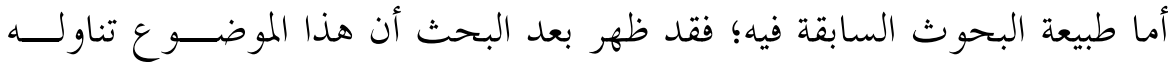

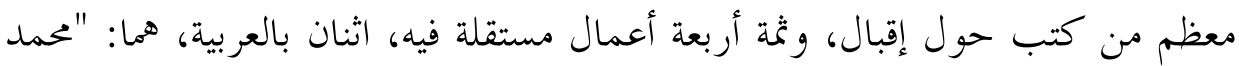
إقبال فيلسوف الذاتية" لحسن حنفي، و "فلسفة الذات في فكر محمد إقبال" لرائد جبار

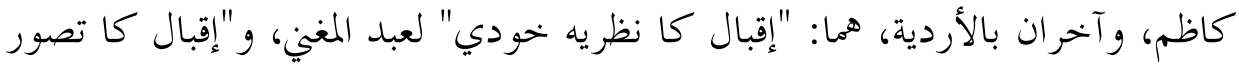

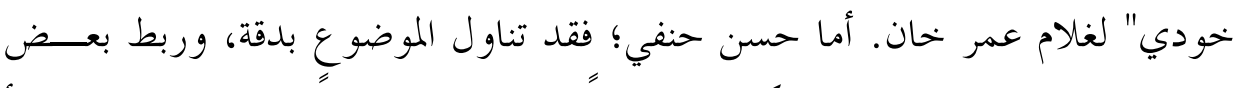

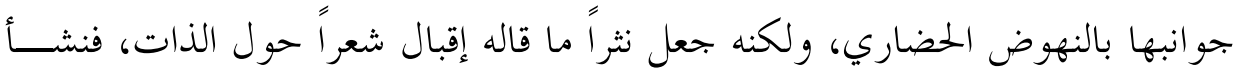

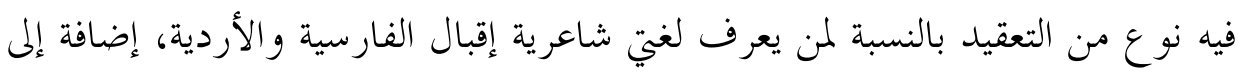

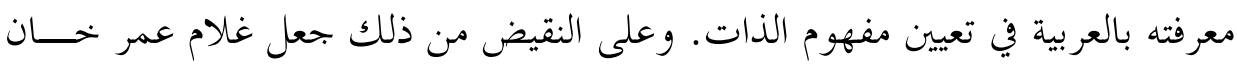

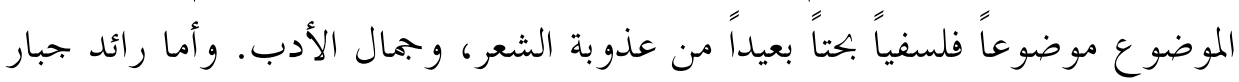

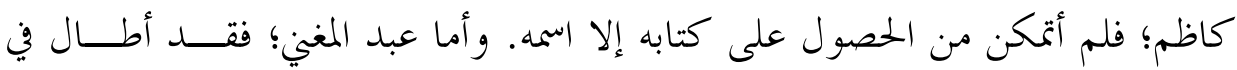

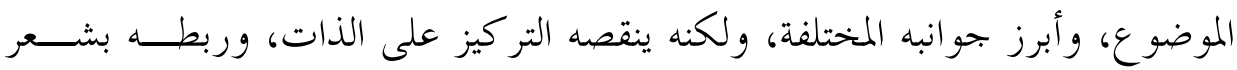

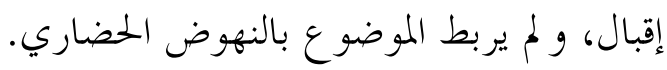
كل ذلك دعاني أن أقوم ببلورة موضوع الذات عند إقبال مـــن شــعره الأردي،

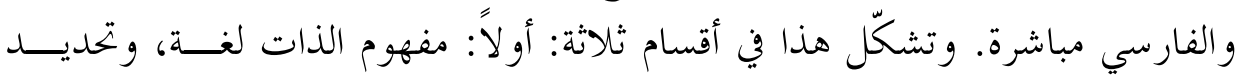

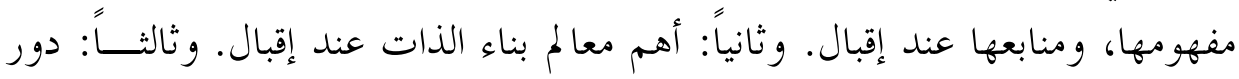

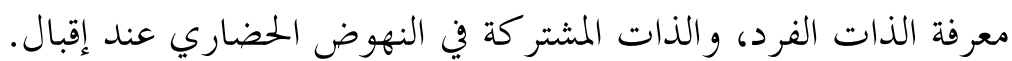

أولاً: مفهوم الذات لغة، وتحديد مفهومها ومنابعها عند إقبال ا ـ الذات في اللغة العربية:

تعني "الذات" وفق المعاجم العربية: "النفس، و الشــخص". ' يقـــــ الكفـــوي:

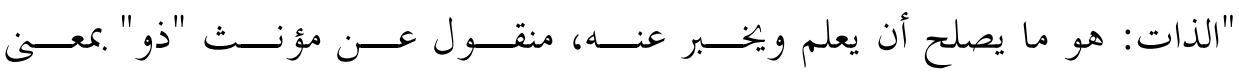

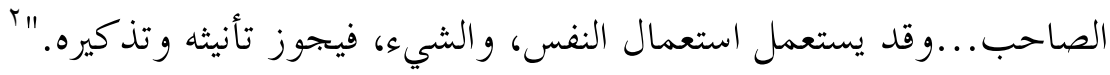

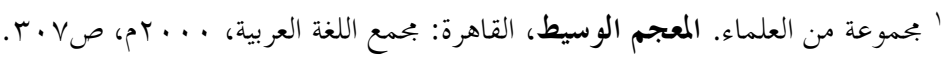


وقد تطور معناها في ظل التغيرات المعاصرة حــتى أصــبحت الــذات مرادفـــة للشخصية، ويتجلى ذلك بما ذكره أحمد مختار عبد الحميد عمر في شرح هذه الكلمة،

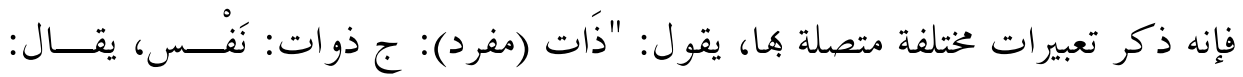

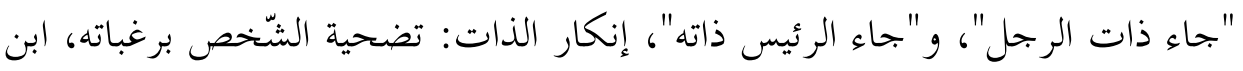

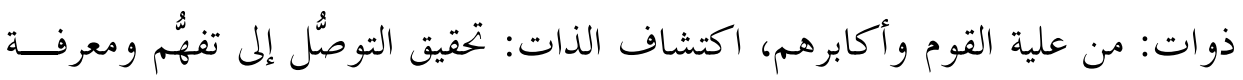

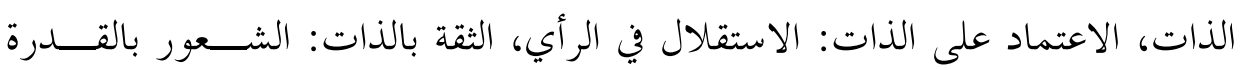
الذاتيّة...تحقيق الذات: تطوير أو تحسين إمكانات الشّخص، وتحقيق الاكتفاء لنفسه....

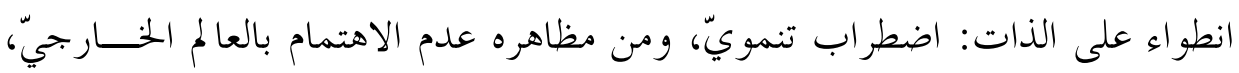

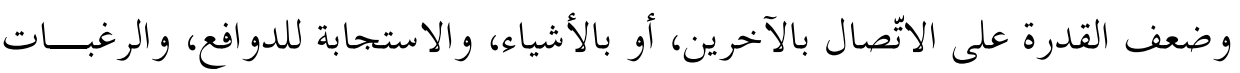

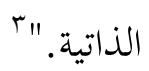

\section{Y ـ الذات في اللغتين الفارسية والأردية:}

وأما كلمة الذات التي ظهرت بالعربية معرّبة لكلمة "خودي" التي استخدمها محمد

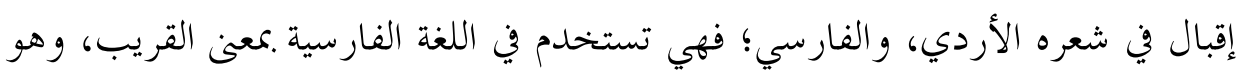

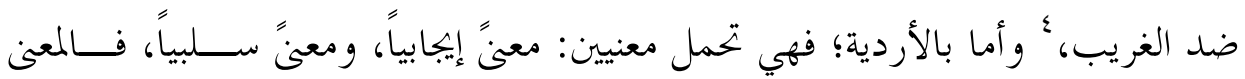

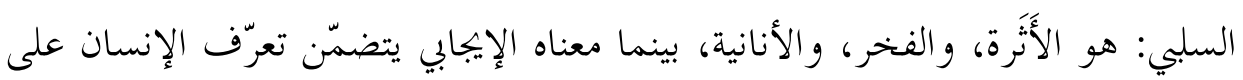

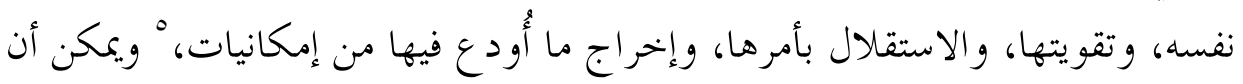

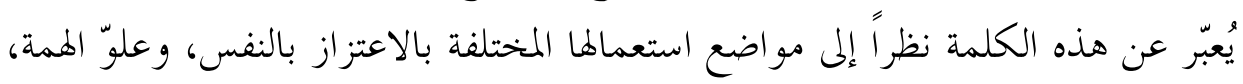

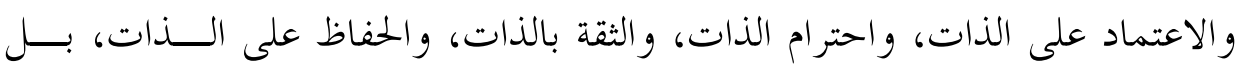

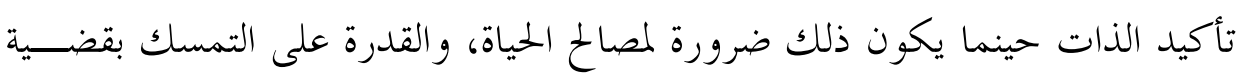

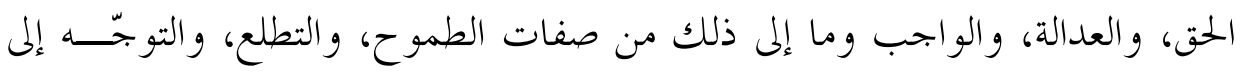

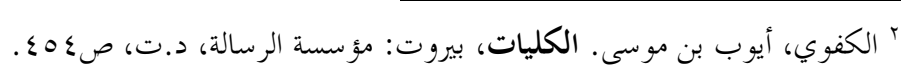

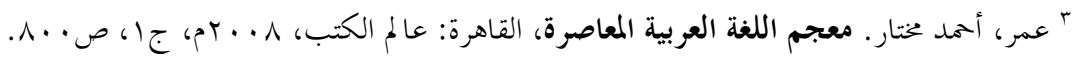

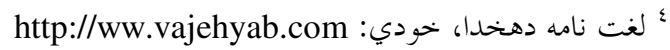

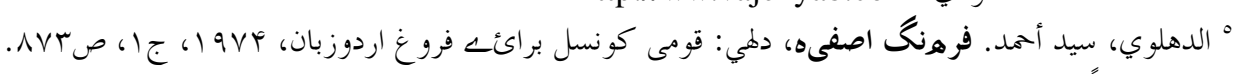
انظر أيضاً: الدهلئ

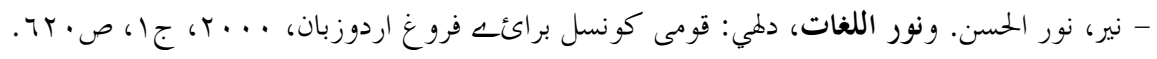


معالي الأمور، والتجافي عن الفتور، والعجز، والميل إلى سفاسف الأمور، ومن المترجمين من عبّر عنها في العربية بالذاتية.

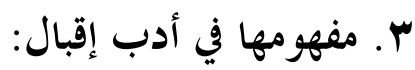

أما إقبال فقد قصد بذلك معناها الإيجابي، فقد وردت في أدب إقبال بمعنى كلمسـة

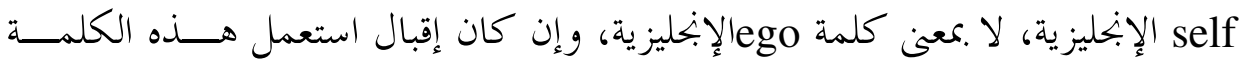

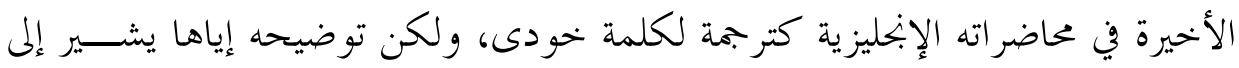

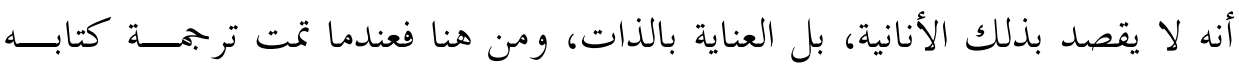

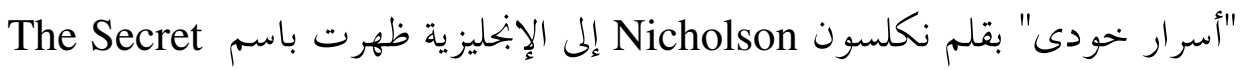
of the Self

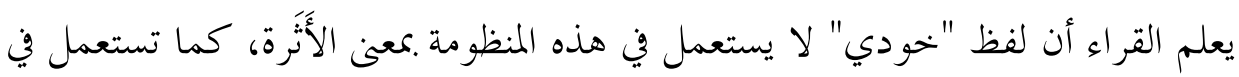

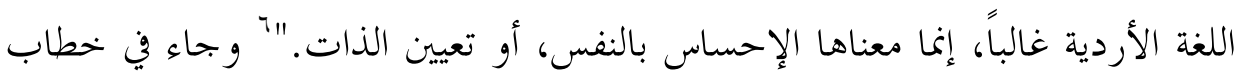

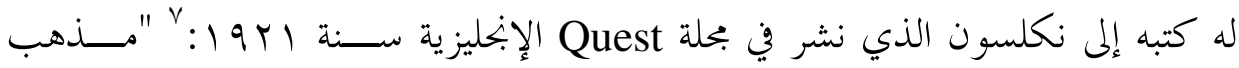

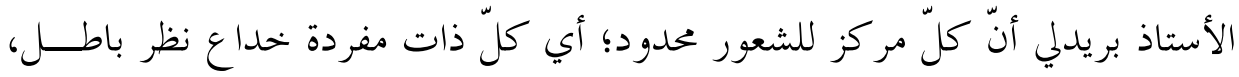

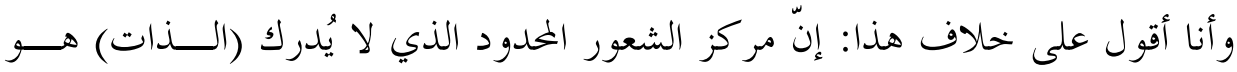

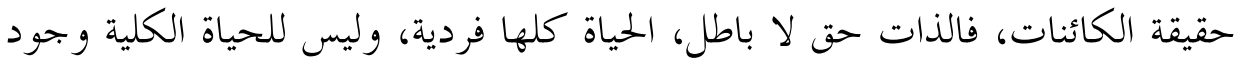

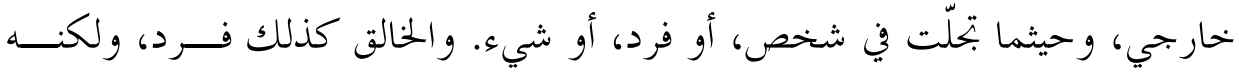

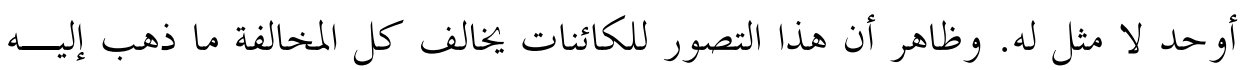

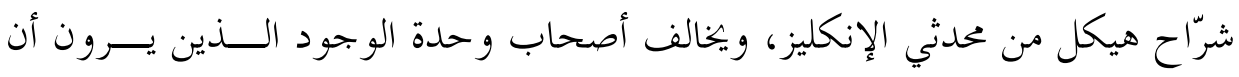

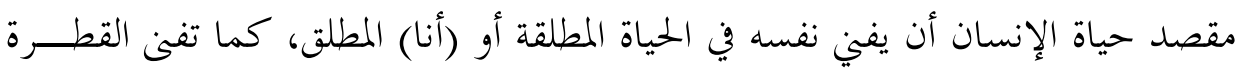

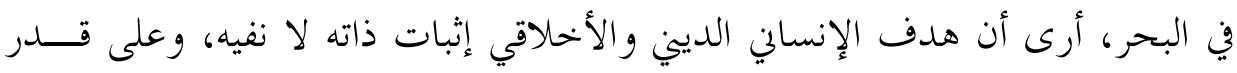

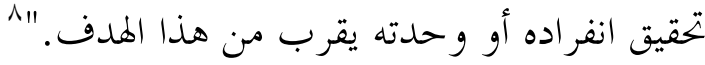

" الغوري، سيد عبد الماجد. ديوان محمد إقبال: مقدمة الأسرار والرموز، تعريب: عبد الوهاب عزّام، دمشق: دار

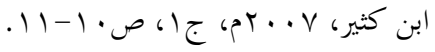

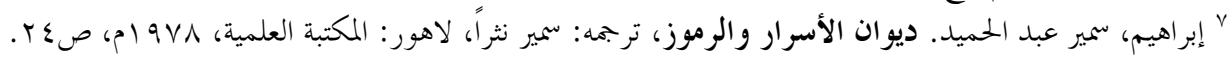

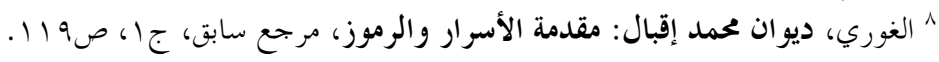


ويظهر من خطاب أملاه محمد إقبال في شرحه لمفهوم خودي على ســيد نــــير

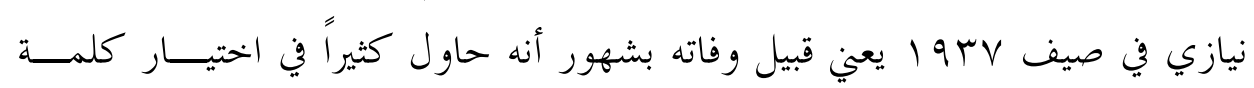

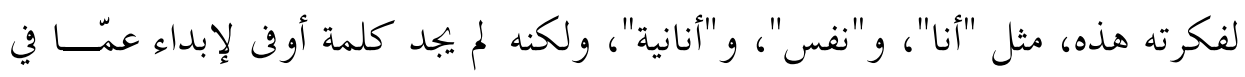

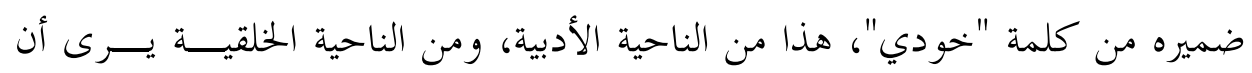

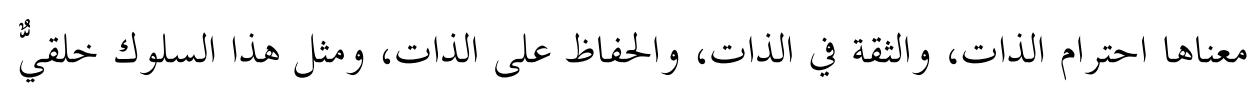

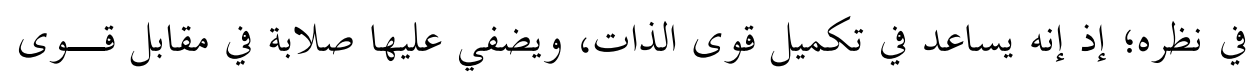

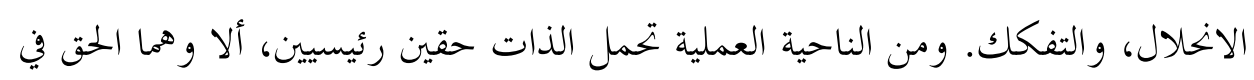

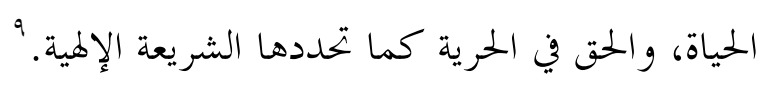

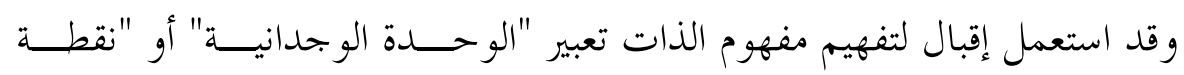

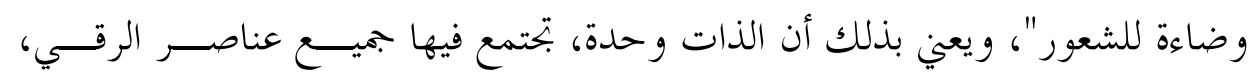

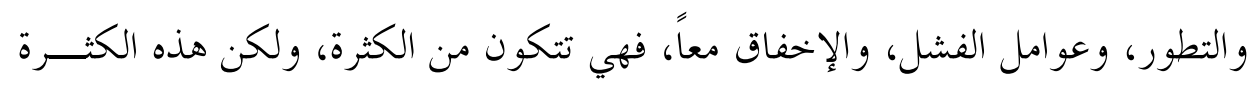

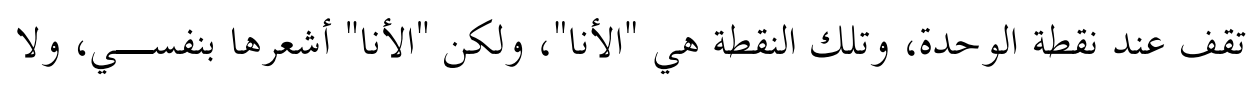

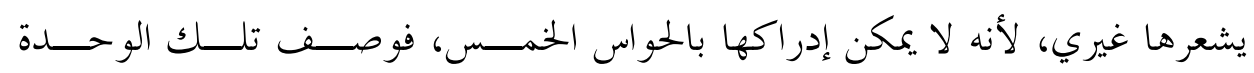

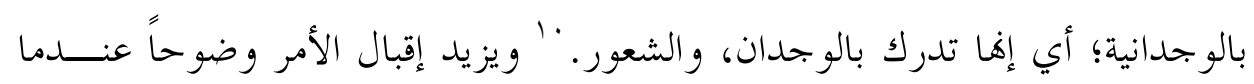

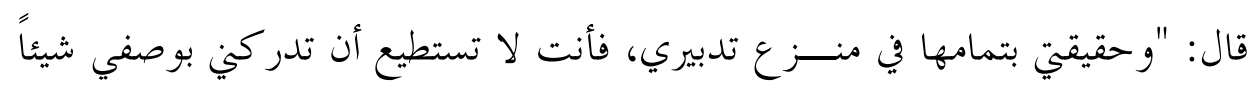
في مكان أو بحموعة من بحارب في نظام زماني، بل يجب أن تفسربي، وأن تفهمين، وأن

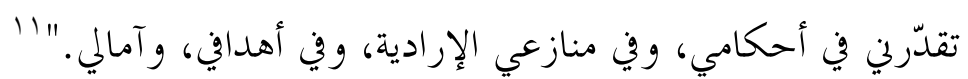

وليس من المعقول تعقيد هذه الفكرة، و التفلسف فيها كما يقول عبـــــ المغــني:

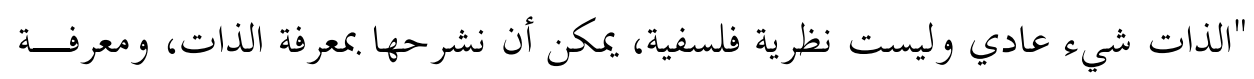

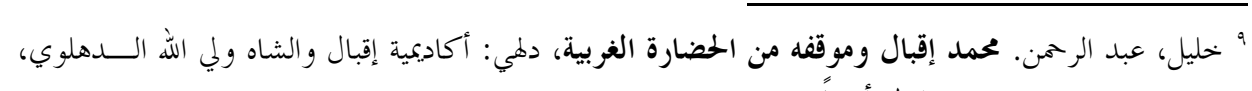

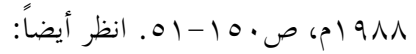

- Razzaqi, Shahid Hussain. Discourses of Iqbal. Lahore: Ghulam Ali and sons, 1979, P. 201-3

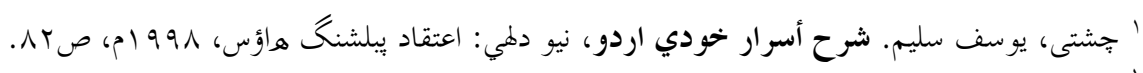

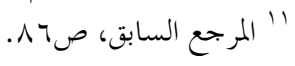


حدودها، وعرفان النفس، وتز كيتها، وتقويتها، وبناء الشخصية، وتربية الجوهر الذاتي،

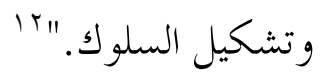

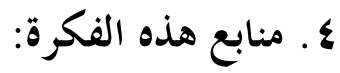

لا شك في أن الفلاسفة وعلماء النفس اهتمّوا اهتماماً كبيراً بمفهــــوم "الــــات"

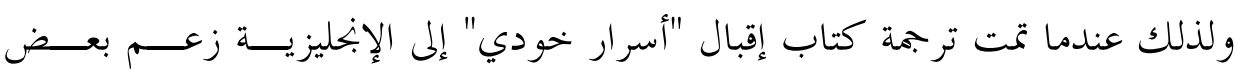

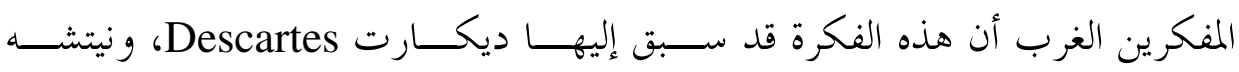
Nietzsche و وهيجل Hegel وشو ونهور Schopenhauer وغيرهم من الفلاســفة الألمان، وثارت شكوك من هنا وهناك في أصالة هذه الفكرة. ويمكن الإشارة في هـــذا الصدد إلى ثلاث وجهات نظر مختلفة، تنتمي إلى ثلاث بيئات فكرية: هندية، وعربيـــة وغربية، أما وجهة النظر الهندية؛ فهناك من يرى أن محمد إقبال قد تأثر بنيتشه، وأخذ

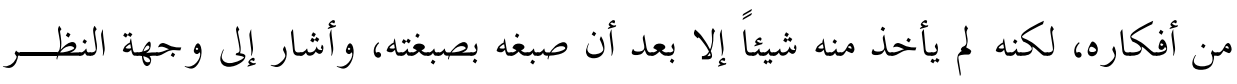

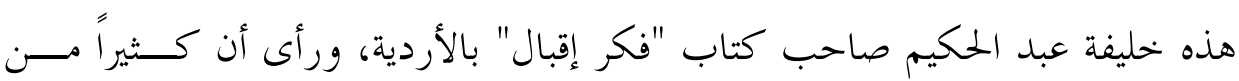
الناس أخطأوا في فهم فكرة الإنسان الكامل عند إقبال، حين شبهوا هذه الفكرة بفكرة الرجل الخارق عند نيتشه، با وأما وجهة النظر العربية فهناك من يرى أنسان أن محمد إقبـــال

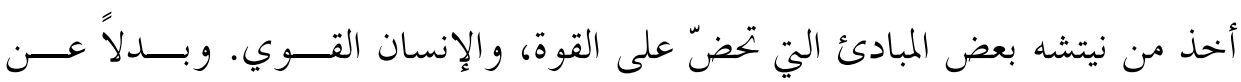

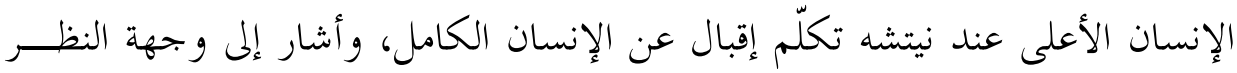
هذه علي حسون. 'أوأما وجهة النظر الغربية فهناك من يرى تشاهاً وتأثراً بين نظريتي

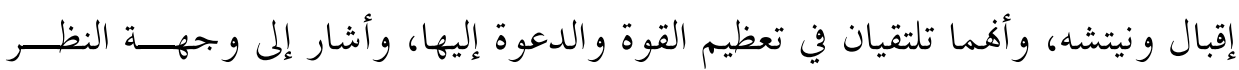
هذه البريطاني دكسن.

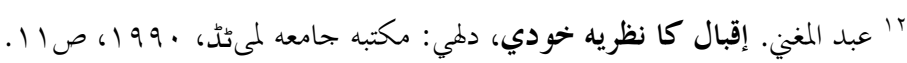

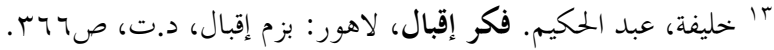

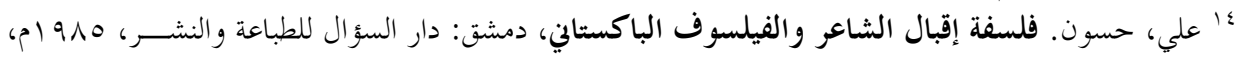

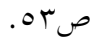

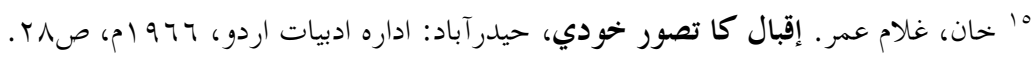


أما وجهة نظر إقبال نفسه؛ فقد نفى بشدة أن يكون قد أخذ من نيتشه، أو تــأثر به، و عدّ من يقول بهذا الرأي أنه لا يعرف الحقيقة، وهذا نصّ كلامه: "كلّ من حاول

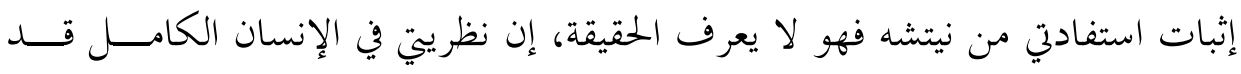
أبديتها و كتبت فيها قبل أن أعرف نيتشه بسنين طويلة، وقد سبق أن نشرت مقالاً في هذا الصدد منذ فترة طويلة، ثم ألحقته في رساليت للدكتوراه عن تطوّر ما وراء الطبيعـــة

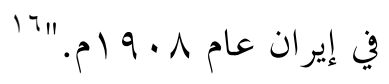

ومن أقوى الأدلة على ذلك أن إقبال لا يكثر الاستشهاد بقوله، حتى قال زكــي الميلاد: "وحين طالعت كتاب "ما وراء الطبيعة في إيران" وجدت أن إقبال لم يأت فيه

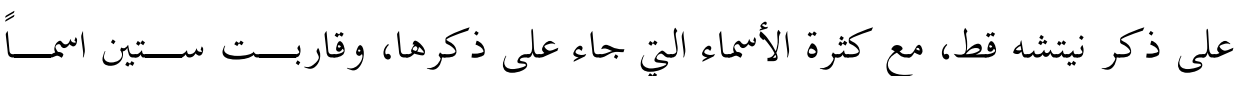

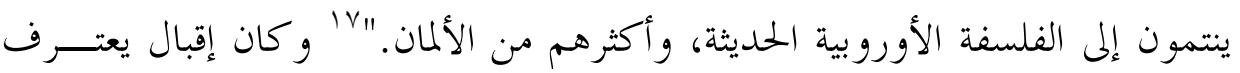
بفضل نيتشه في العلم، و بأنه فيلسوف كبير، و نافذ البصيرة، وو ضعه تحـــت عنــــوان: "الحكيم نيتشه". "1 و ولكنه نقده بعدم معرفته التوحيد، و القلب، و العشق، فكأن هذا هو الفرق البيّن بين فكره و فنكر نيتشه.

\section{أ. المنبع الحقيقي لهذه الفكرة هو القرآن والتصوف الإسلامي:}

محا لا ريب فيه عندي أن إقبال استقى فكرته عن الذات من القر آن الكريم، فهـــو يذكر في محاضرة ألقاها عن الذات الإنســـانية بعنـــــان: The Human Ego-His freedom and immortality فهناك ثلاثة أمور و اضحة كل الوضوح في القر آن:

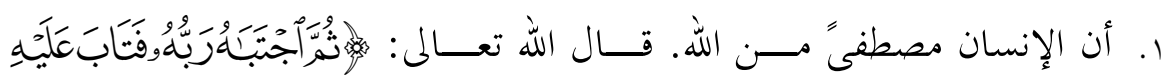

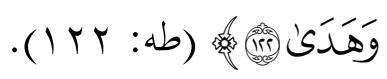

$$
\text { } 17 \text { المرجع السابق، صهم. }
$$

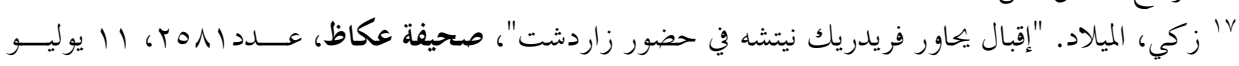




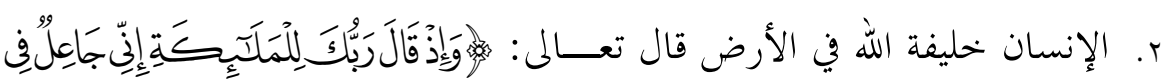

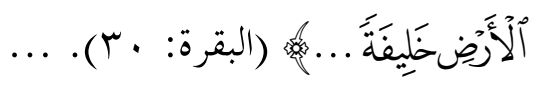

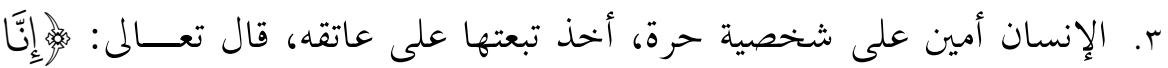

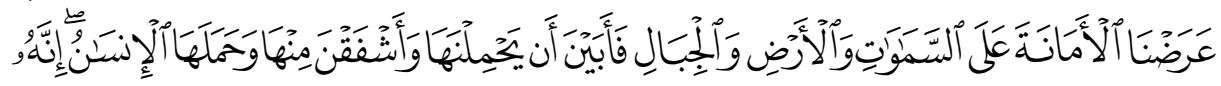

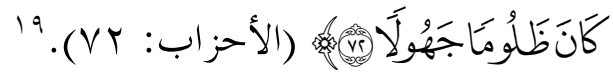

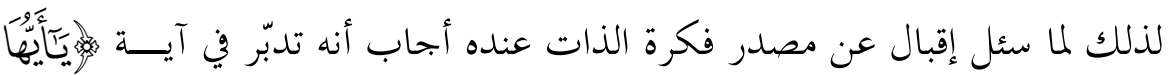

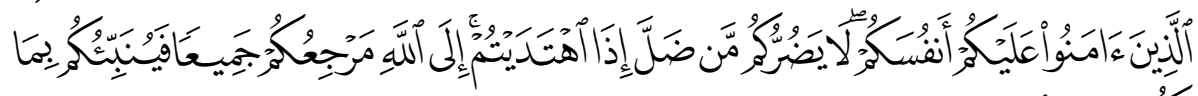

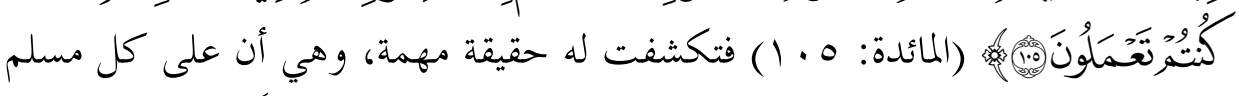

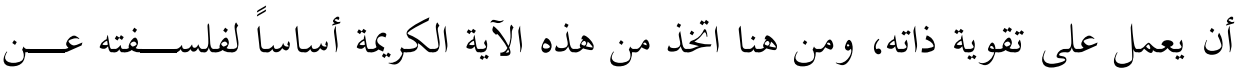

$$
\begin{aligned}
& \text { الذات، ‘ُ يقول في ديوانه "زبور العجم": }
\end{aligned}
$$

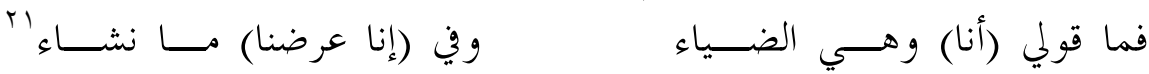

إضافة إلى ذلك استفاد إقبال في تبني هذه الفكرة من التصوّف الإسلامي، وهـــل

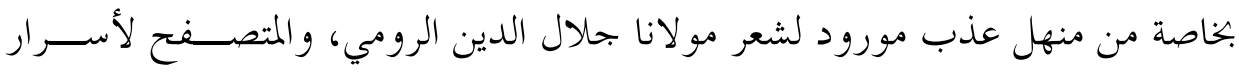

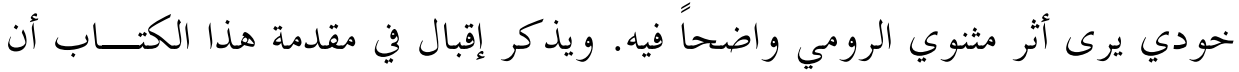
الرومي هو الذي أيقظه، ونبهة، ودعاه أن يسلك هذا السبيل، وينشر في الناس أفكاره، و يبلغهم رسالته، وهو يعترف للرومي بالإمامة في كثير من أشعاره، ولما نظـــم إقبـــال

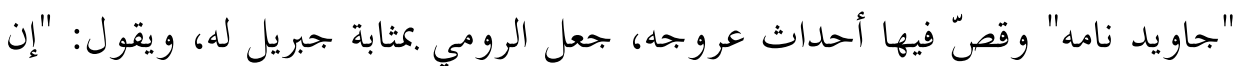

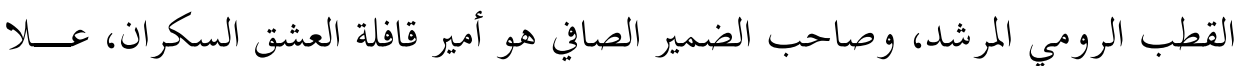

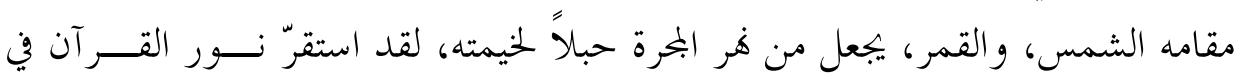

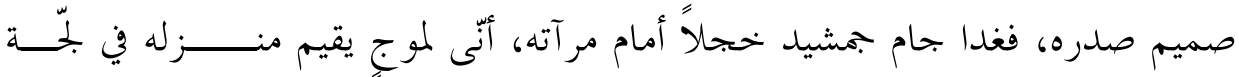

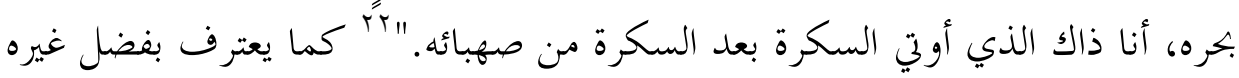

${ }^{19}$ Muhammad Iqbal. The reconstruction of religious thought in Islam. Dodo Press, 1930, P. 113.

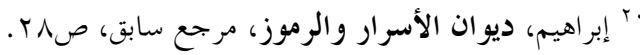

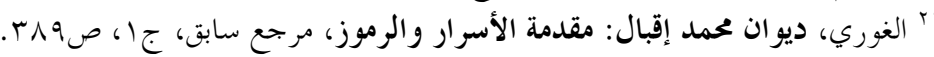

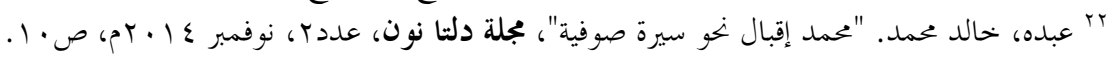


من عظماء الصوفية، فيقول: "إنين أعلن أن فلسفة أسرار خودي برمتها مأخوذة مـــن

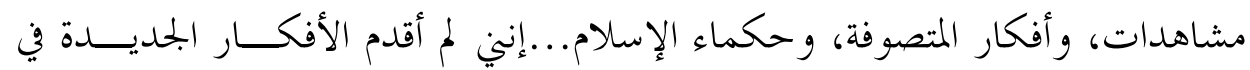

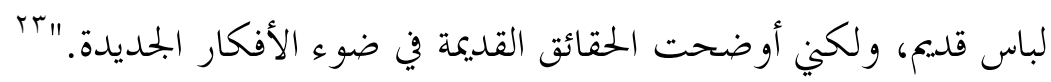

\section{ب. الفرق بينه وبين الصوفية في هذا الصدد:}

أثبت إقبال أن الذات شيء بدهي، وهو أن كلّ إنسان يستطيع أن يســمع نـــــاء

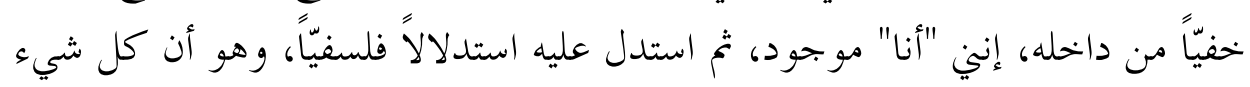
من أشياء العالم يمكن أن يقع الشك في وجودهه، ولكنّ الشيء الوحيد الذي لا يقع فيه

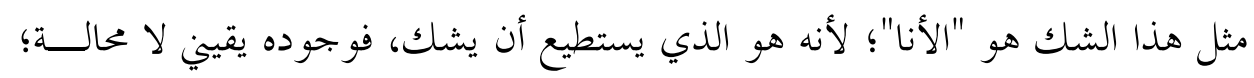

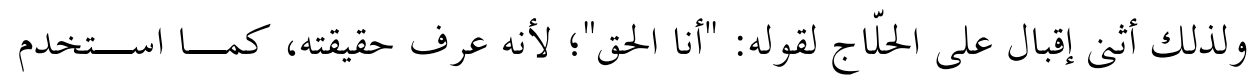

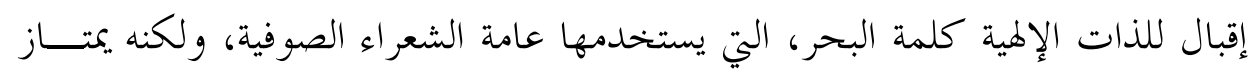

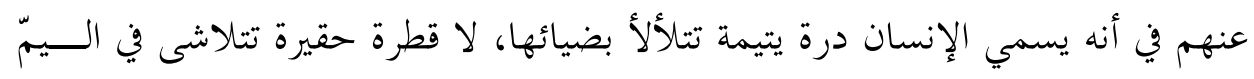
كما يقول بعض الصوفية.

و إقبال لا يقول .كمألة وحدة الوجود، وإنما يؤ كد على أن الذات الإنسانية شـيء

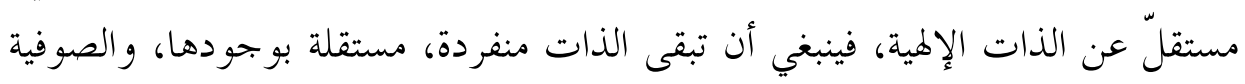

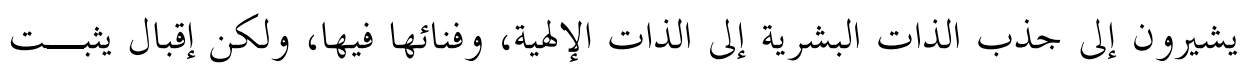
بتشبيه شعري بليغ أنه يهلو لكل شيء من أشياء الكون أن يهافظ على ذاته، ويستوفي

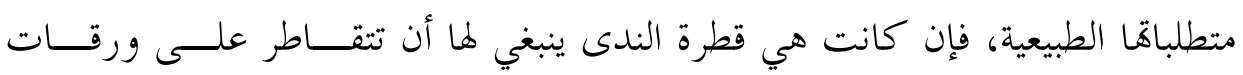

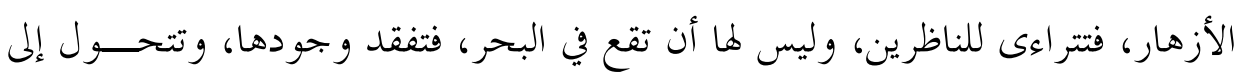

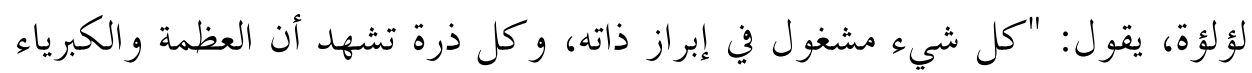

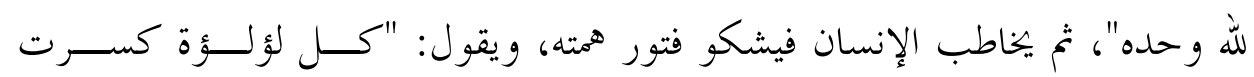

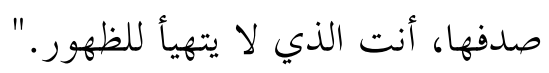

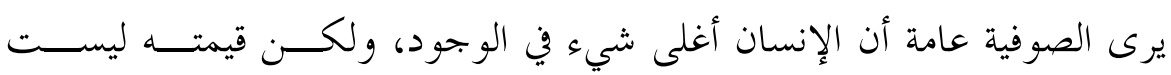
بإنسانيته، وإنما لأجل أن نور الإله الحقيقي يظهر فيه، ولكنّ إقبال يركز على أنس أن شرفه

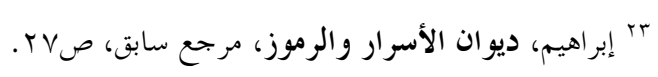


لإنسانيته، وهذه هي المكانة السامية للشرف الإنساني التي كشــف عنــــها إقبـــال في

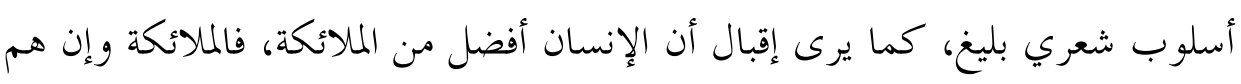

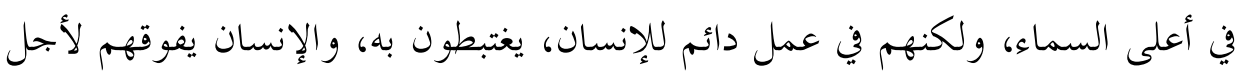
ذاته، وأن الإنسان هو المطلوب الحقيقي للذات الإلهية، وهو في بحث مستمر للإنسان، فالصوفية يقولون: إن نور الإله يتجلى في كل شيء، وإقبال يقول: يتجلى كي يبحث

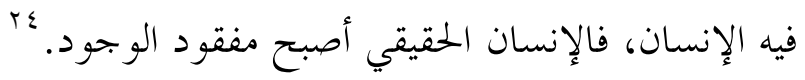
و يتجلى من هذه الفروق أن إقبال لم يأخذ هذه الفكرة بكاملها مــن الصـــوفية

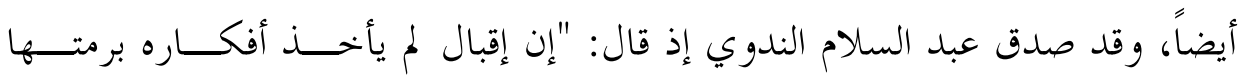

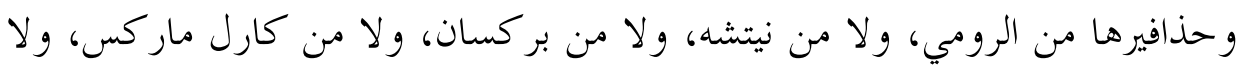

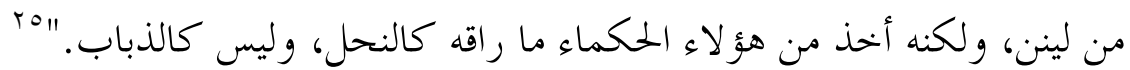

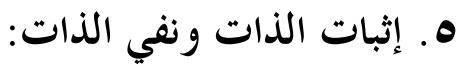

يمكن اختز ال فلسفة إقبال عن الذات في مبدأين؛ الأول: إثبات الذات، و الآخــر:

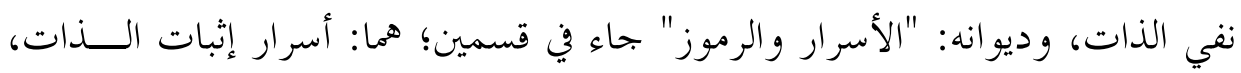

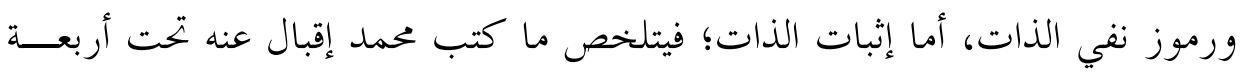

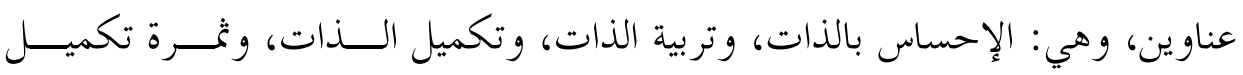
الذات.

الإنسان مطلع على ذاته، ولكنه يحتاج إلى إثباته للآخرين لمن لا يدر كها، وربما لا

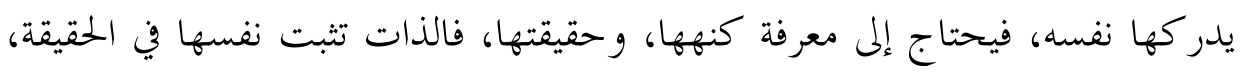

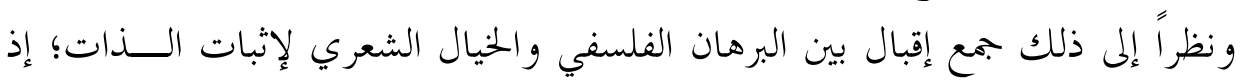
يقول بياناً لأهميته:

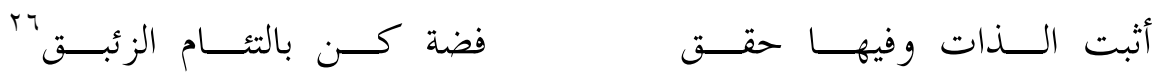

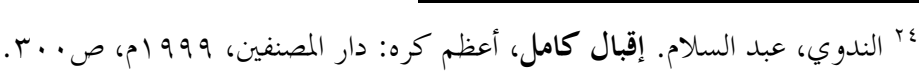

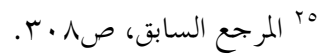

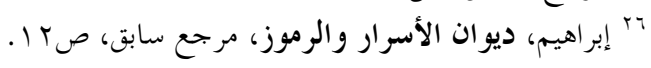


و يشبّه الذات بالبحر، ويشير إلى ما يقويها، وما يضعفها، فيقول: "الذاتيــة هـــي

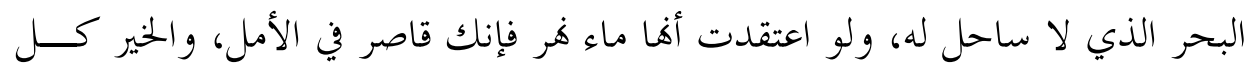

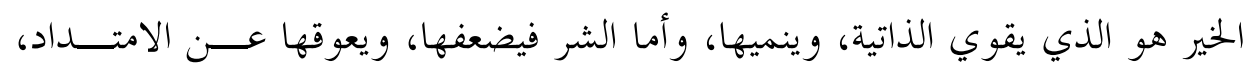

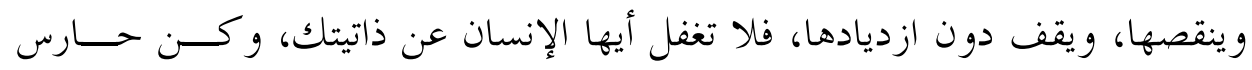

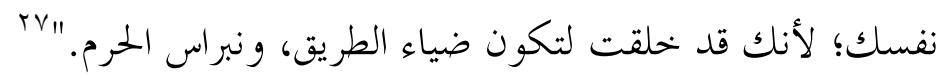

\section{أ. مراحل إثبات الذات: - n}

يرى إقبال أن الذات في رحلة إثباها تمر بثلاث مراحسل حسل حـت تصــل إلى ذروة كماها، وهي الحنالافة في الأرض، وذلك على النحو الآتي: - إنشاء المقاصد، وتعيين الأهداف، وتوليد الرغبات: ويعني بــــلك أن حيــــاة الذات بالأمل الدائم، وذلك بأن هناك رغبة نطلب تحقيقها، وتحقيق القصد هو الــــي

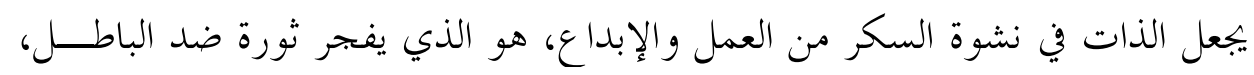

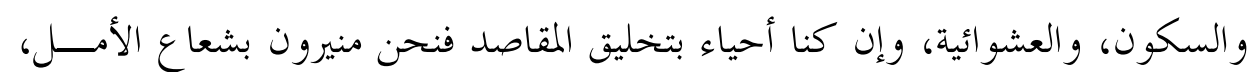

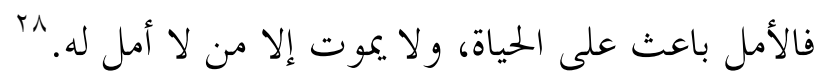

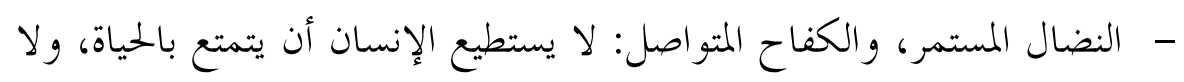

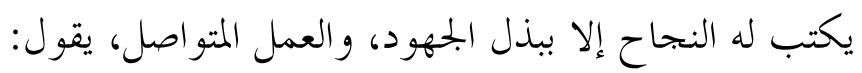
فاخلق لروحك من زئيرك نشوة

و يشترط محمد إقبال لهذه المرحلة شروطاً أساسية، أهمها: الطاعة، وضبط النفس،

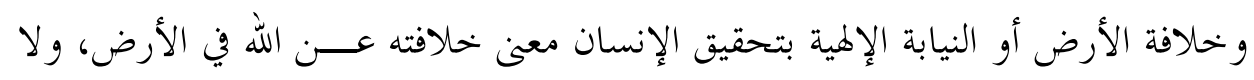
يتحقق ذلك إلا للمؤمن الكامل.

بل الصاوي، علي شعلان. إيوان إقبال (مختارات من شعره)، مصر: اللجنة الباكستانية المصرية للاحتفالات المئوية

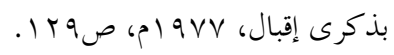

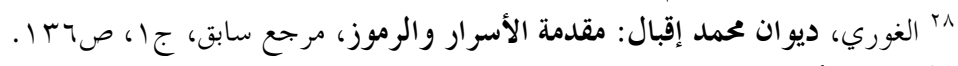

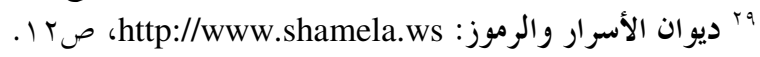

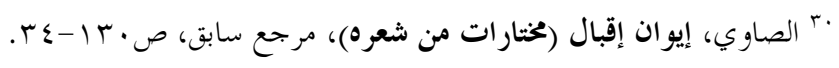


- المؤمن الكامل الذي يمثل آخر قوة خودي، ولا يتحقــق ذلـــك إلا بتعــيين الأهداف، والجهد الدؤوب، فهذا الإنسان عزيز النفس لا يقبل الإهانة، صبور في كل ئره

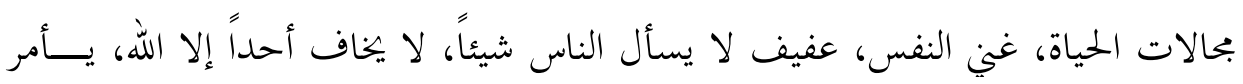

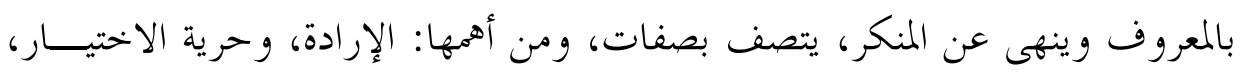

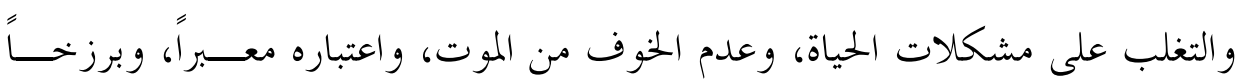
للخلود، وتسخير الكائنات، وإخضاع الوجود، وعدم الافتنان بالدنيا، و الجو انب المادية

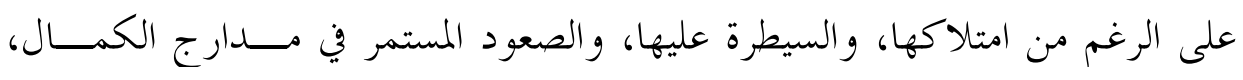
و التقرب إلى الذات الإلهية المطلقة، وهي ذات ذات الله سبحانه و تعالى، يقول:

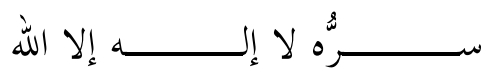

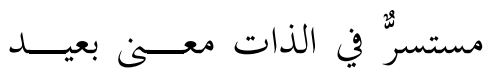

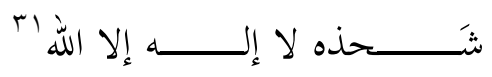
سيف الذات قاطع غـــر نــاب

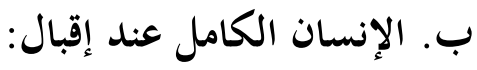

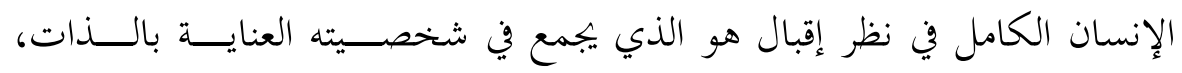

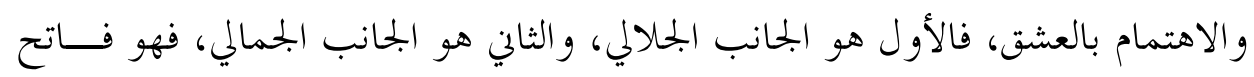

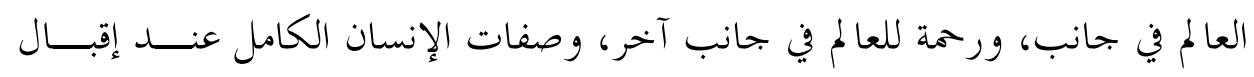

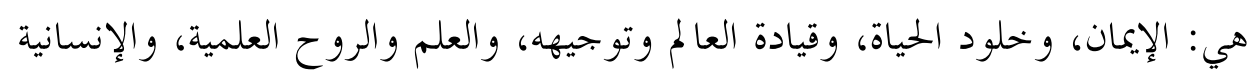

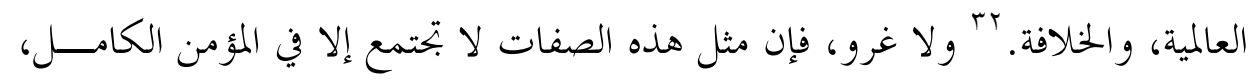

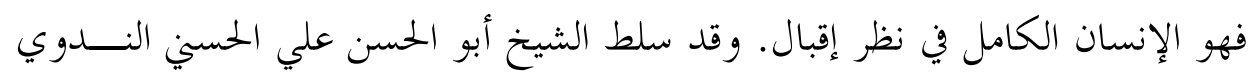

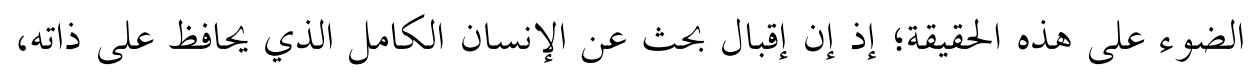

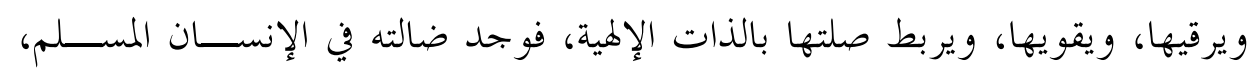

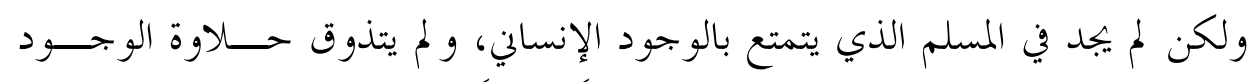

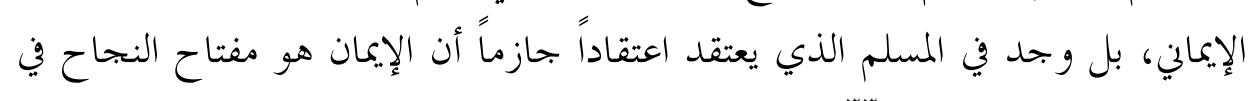

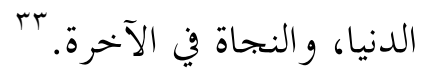

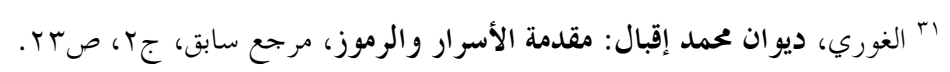

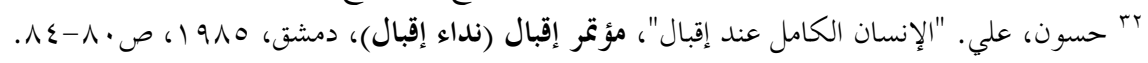

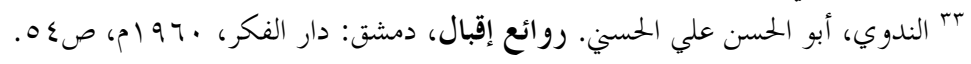


إن صورة الإنسان الكامل التي قدمتها يمكن أن تنطبق على كل رجـــل مـــؤمن؛

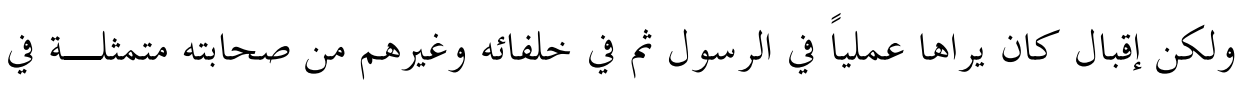

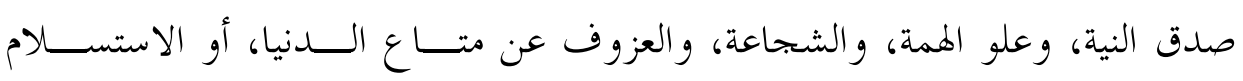

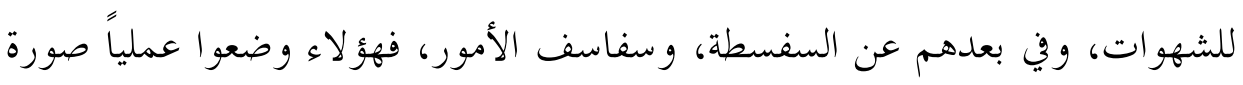

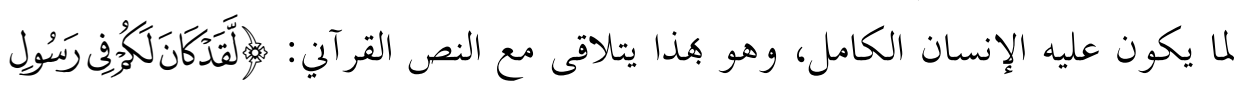

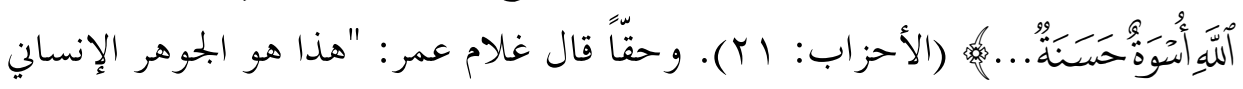

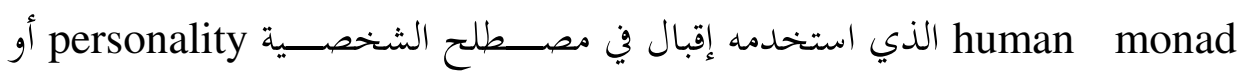
"خودي"، وهذا هو الذي ينحصر على تشكيله نشأة الشخصية العملاقة أو الإنســان

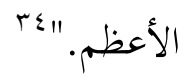

\section{ت. نفي الذات أو اللاذاتية:}

على الرغم من تأكيد محمد إقبال على وجود الشخصية والذاتية لكل فرد، فإنــــ

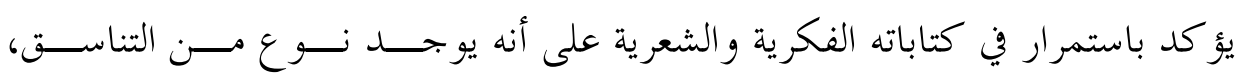

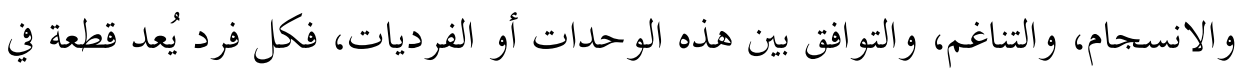

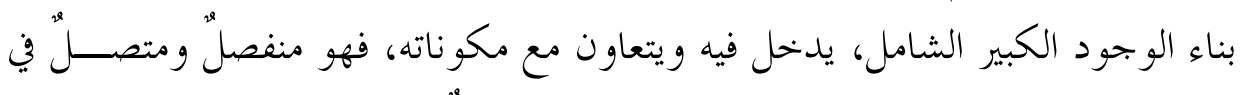

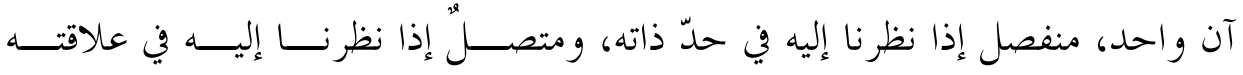

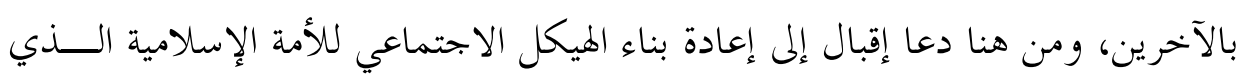

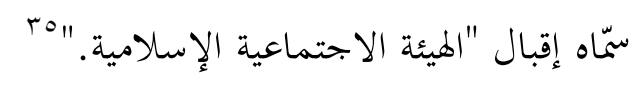

إن تعبير نفي الذات يوهم أنه ضد تصور الذات، والشخص العادي لا يستطيع أن يدرك الفرق الدقيق بينهما كما يقول إقبال نفسه:

أنت لا ريب من الشك ردى

$$
\text { أنت لم تعرف خودى من بيخودى }
$$

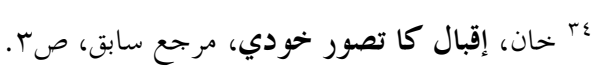

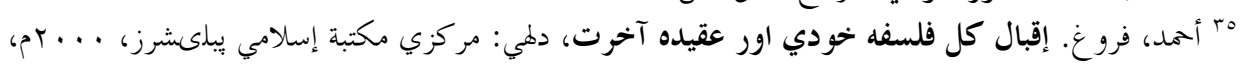

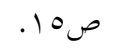
Trm الغوري، ديو ان محمد إقبال : مقدمة الأسرار والرموز، مرجع سابق، جr، ص19 1. 
لكنه في الحقيقة يفسر النظرية نفسها ويبينها، وتُعد التتمة اللازمة لها، ولتوضــيح ذلك كتب إقبال منظومة مستقلة باسم "رموز بيخودي" (رموز نفي الذات)، و الحقيقة أن هذا التصور بمثابة الإخلاص Selflessness للآخرين، وإيثار الآخرين على النفس،

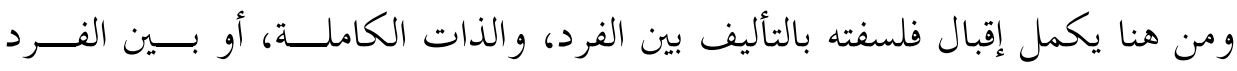
و الجماعات التي يعيش بينها. ويمكن أن يقال: إن إقبال يدعو إلى تكوين بحتمع مثــــالي

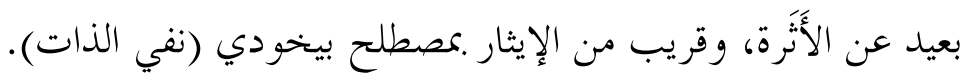

\section{ثانياً: معالم بناء الذات عند إقبال}

سوف أحاول القيام بإبراز جوانب من أدب إقبال يستدل هـا على الطريق إلى بناء

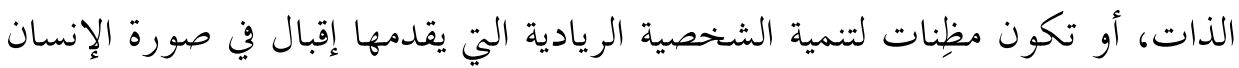

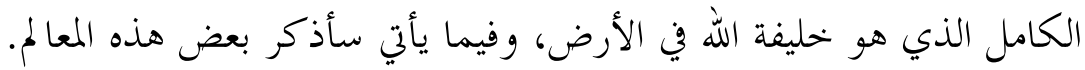

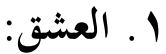

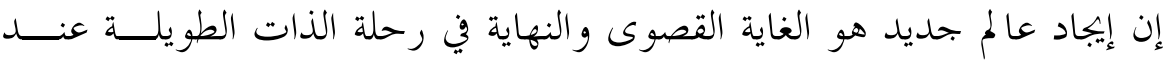

إقبال، وهي تتقوى بالمحبة، والعشق، ولكن ما هذا العشق الذي يتحدث عنه إقبال، وما

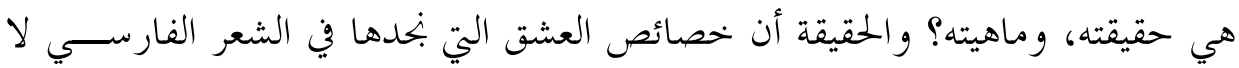
يوجد لها نظير في الشعر العربي، يقول عبد السلام الندوي: "إن فلسفة الإشراق هـــي

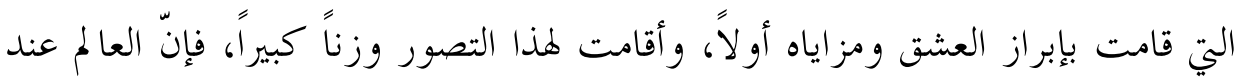
الإشراقيين قائم على نظام "القهر و المحبة"، و إليهم مال إخوان الصفا، فقدّموا تصوّرات

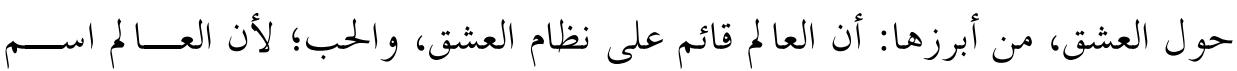

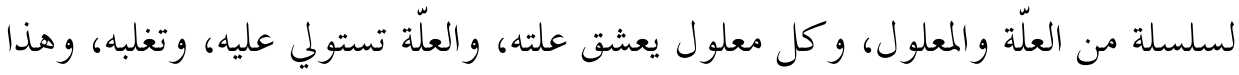

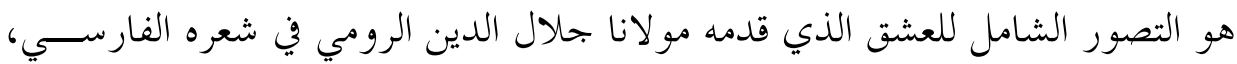
و الشعراء الفرس عندما أبصروا الكون من خلال هذه الرؤية جعلو الكل اثنين بينـــهما

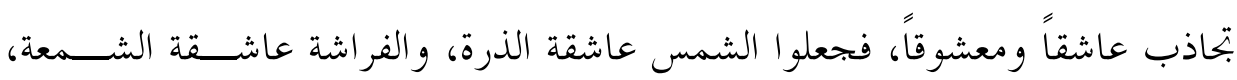

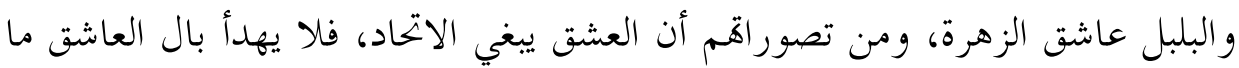


لم يتحد بالمعشوق، وهذا هو التصور الذي أوجد مسألة وحدة الوجود، وأراد الصوفية

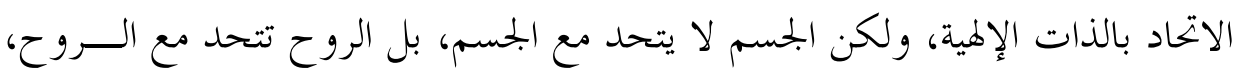

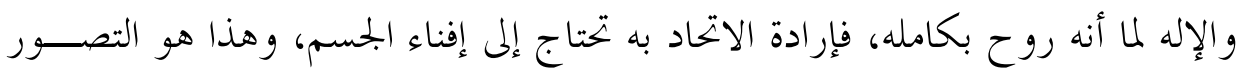

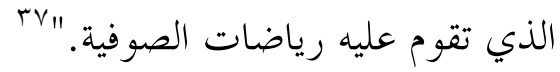

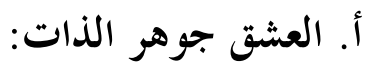

يعترض الغرب على الإسلام أنه ليس عنده تصور العشق، ومن تم نشأ في أتباعــه الزهد الجحاف، فأثبت إقبال أن العشق جوهر الذات، وأنه يوجد في الإنسان البصــيرة الثاقبة، والقوة المتدفقة، و يعرفه حقيقة لا تقيدها الزمان و لا المكان، العقل يسخر العالم

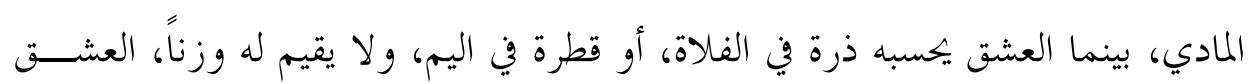

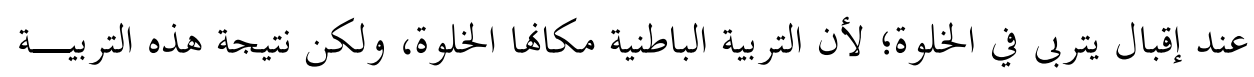

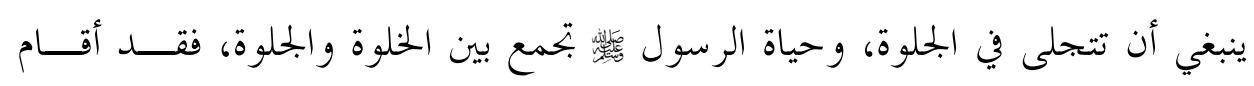

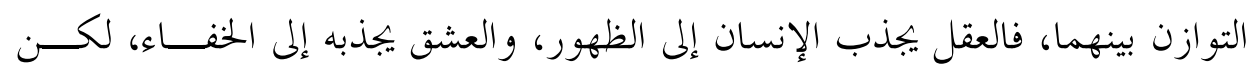
الحياة لا تكتمل إلا بإيجاد التوسط بينهما.

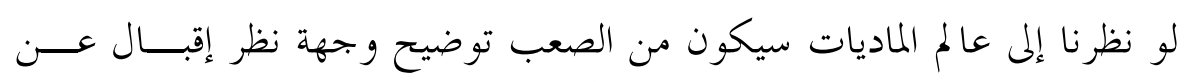

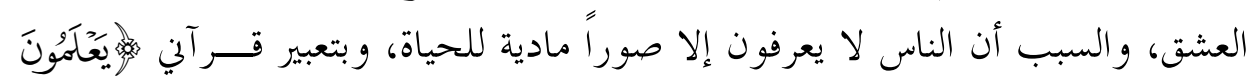

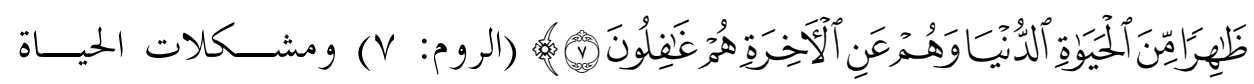

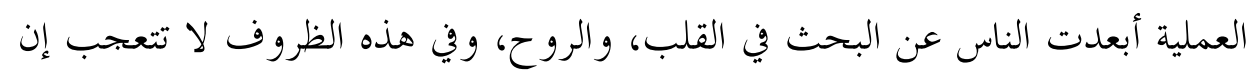
بدا هذا الموضوع و كأنه لا يزيد عن كونه تخيل شاعر، ولكن الحياة هي بحربة إبداعية،

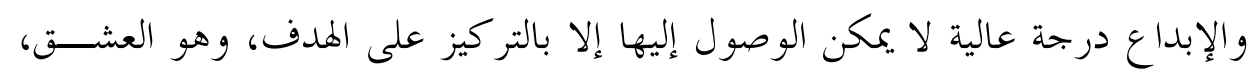

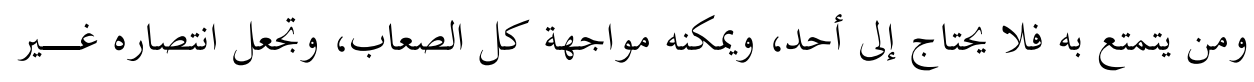
محدو د.

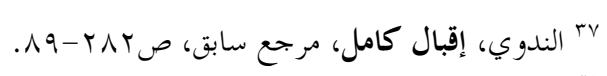

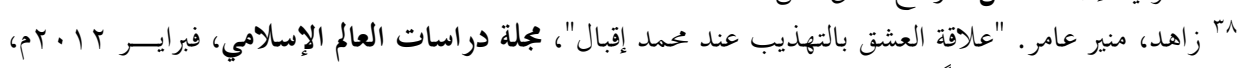

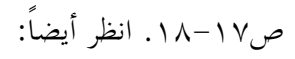


ويرى إقبال أن أهل الشرق، وهم المسلمون، وإن أصيبوا بالتخلف، ورلكن قــوقم

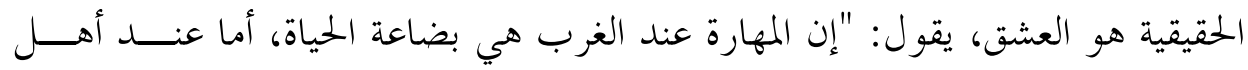

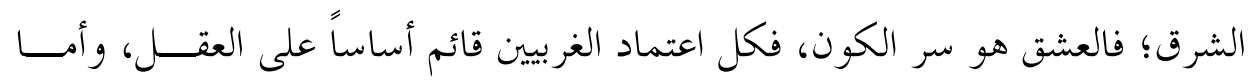

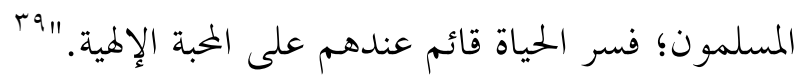

\section{ب. صلة تصوره عن العشق بالتصوف الإسلامي:}

في تصوّره عن العشق في منظومة "رسالة العشق" أثبت إقبال أن الصــلاة رمــز

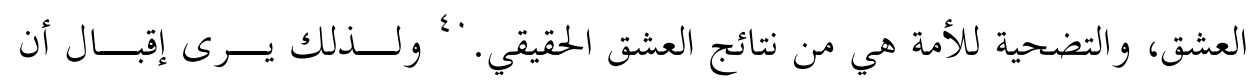
التصوف الذي لا يستطيع أن يأتي بثورة في حياة الإنسان، ولا يتجاوز من لذة العشق،

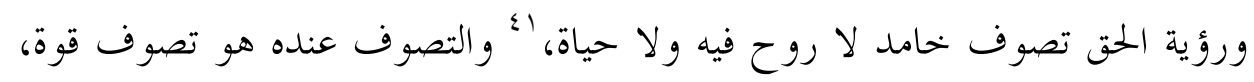
وليس تصوف خضوع، وكسل، وهزيمة، وانكسار، وإنكارٍ للذاتية. ومن هنا يلتقــي

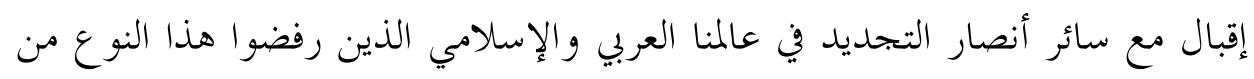

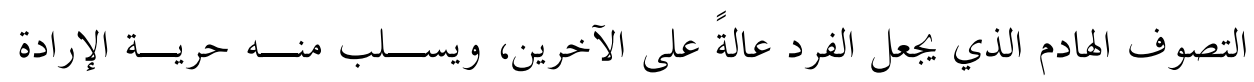
الإنسانية، كما يتبين من أبياته الآتية من دواوينه المختلفة:

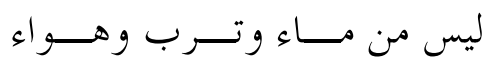
لا يهاب العشق في السيف المضاء

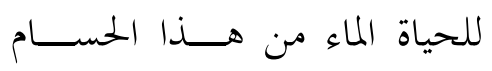

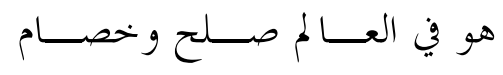
هو عشق الحق والحـــق يصــير نظرة العشق هها شــــ الصـــخور

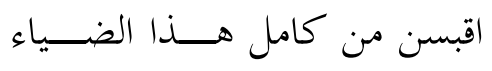

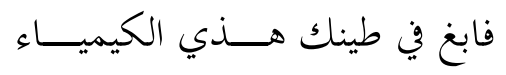

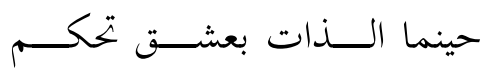

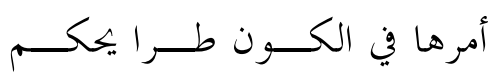

- شيمل، آنا ماري. أسرار العشق المبدع، لندن: نشرة مؤسسة الفرقان، 991 ام ام.

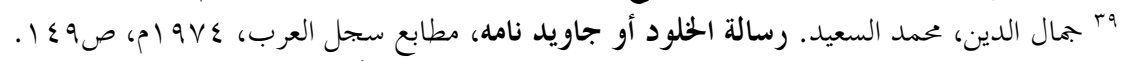

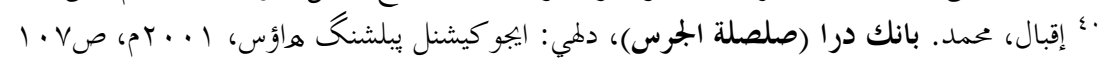

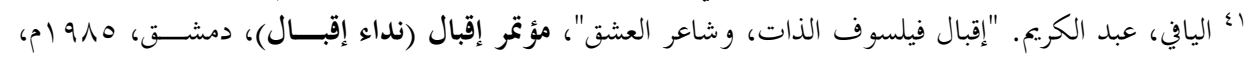




\section{ت- تسخير الكون:}

من أبرز مظاهر العشق تسخير الكون، فإن كل شيء يجذب ما حوله إلى نفســه،

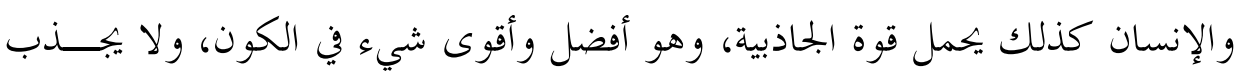

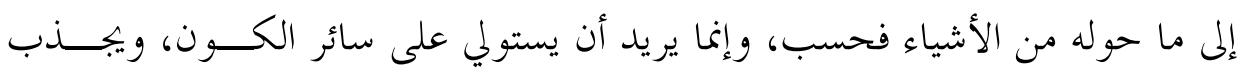
العالم بأكمله إلى نفسه، وهذه الجاذبية هي تسخير الطبيعة، قال إقبال:

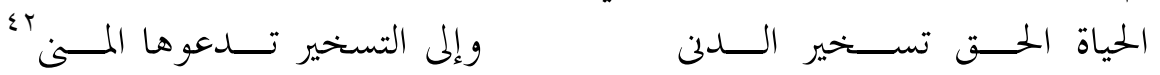

ولها صور ومر احل مختلفة، وأعظم صورها أن الله هو الذي سخّر له الكــــون، قـــال

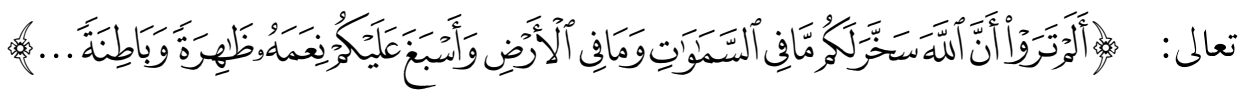

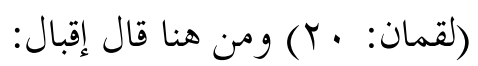

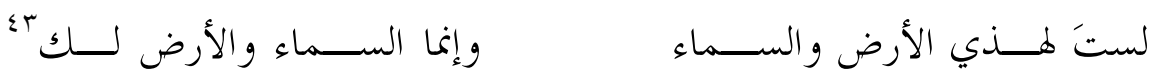

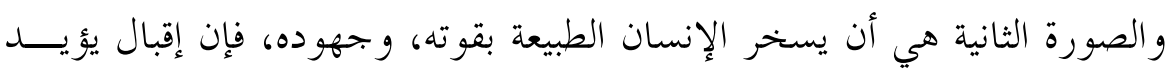

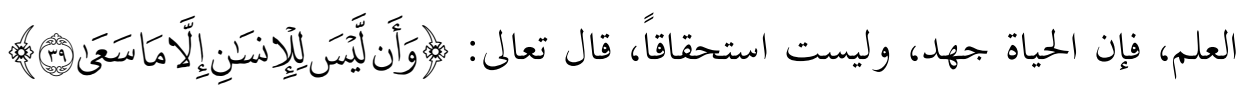
(النجم: وץ) و الصورة الثالثة أن يسخّر الإنسان الطبيعة بطاقاها الروحية، وهذه الطاقة

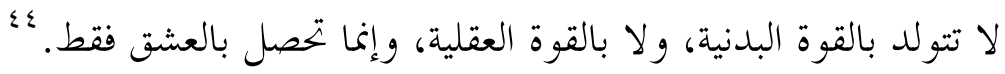

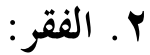

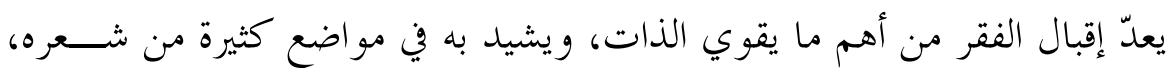

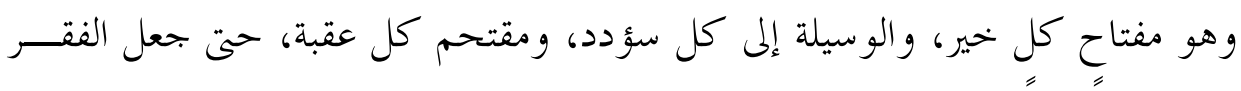

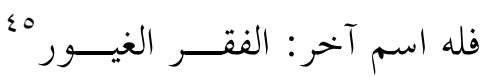
الغيور اسماً ثانياً للإسلام، يقول: إن قلى الغرب من الإسلام لفظاً

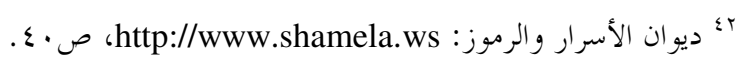

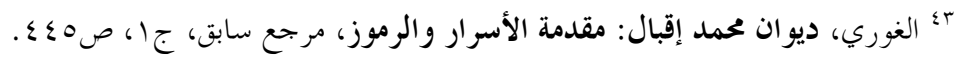

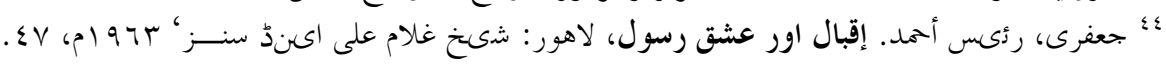

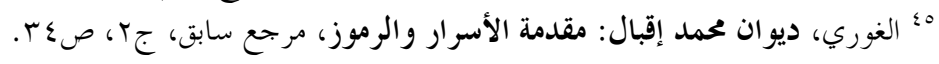


يتبين من التأمل في شعر إقبال أن الفقر الذي يعنيه هو خلاص النفس، والذات من

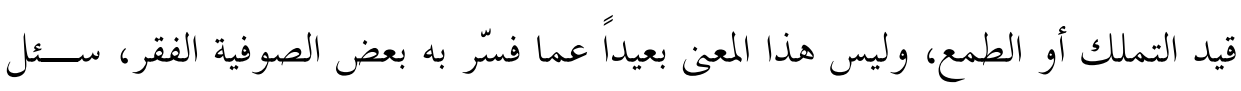

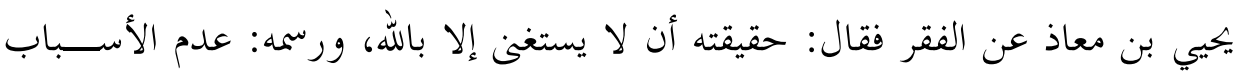

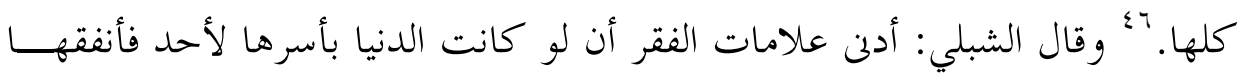

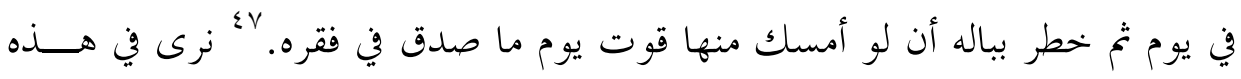

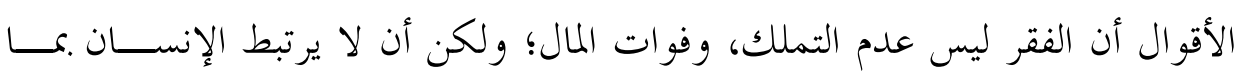

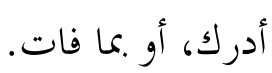

يفرق إقبال بين الفقر و التسوّل، فهو يريد أن يرى في المؤمن صفات الفقـــر، ولا

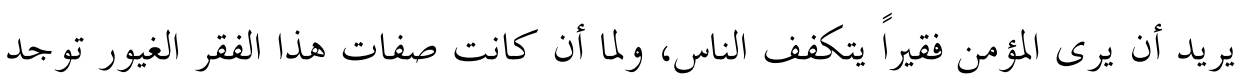

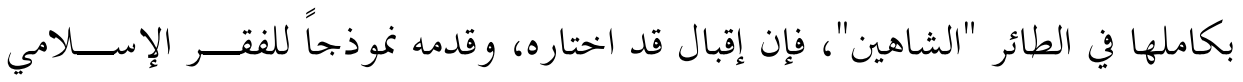

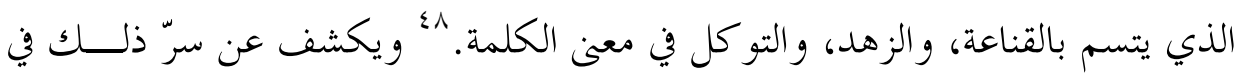

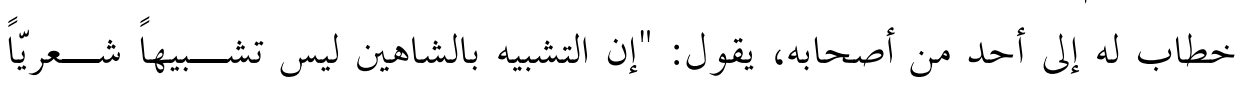

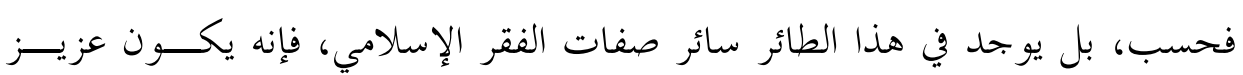

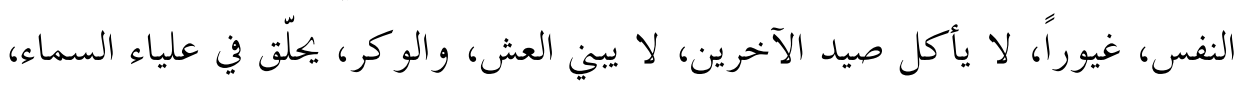
يحبّ الخلوة، و نظرته دقيقة فاحصة. "9.

وقد بدأ تصور الشاهين عند إقبال في "رسالة الشرق" فذكر قوتــهـ وعزمــه، وأن

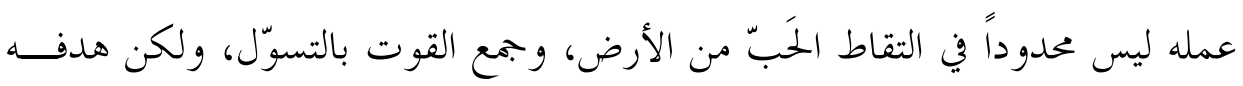
المنشود هو توسيع حركة الحياة، والزيادة في قدر القوة، ويكــــون طيرانـــهـ في عنــــان

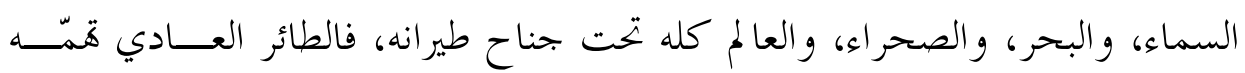

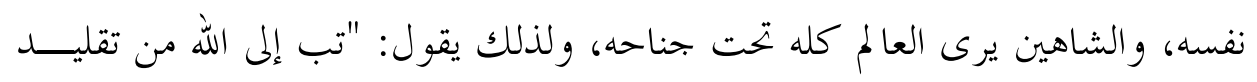

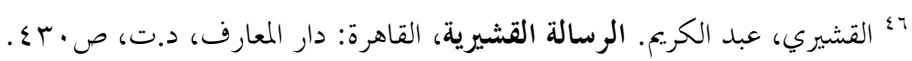

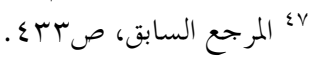

${ }^{48}$ Sharif ,M.M. About Iqbal and his thought. Lahore: Inst. of Islamic Culture,1976, p.37.

9؛ عثماني، طيب. إقبال شخصيت اور بٕيهام، دلي: مركزي مكتبة إسلامي ببلكشرز، و9 19م، ص101. 


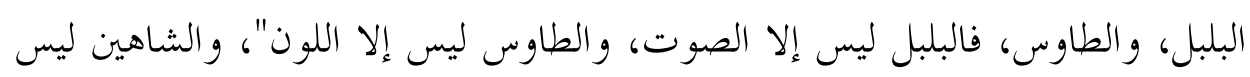

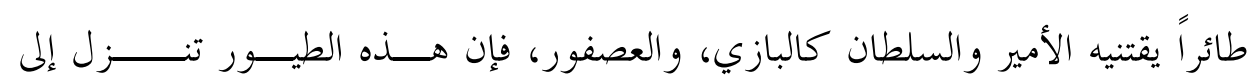

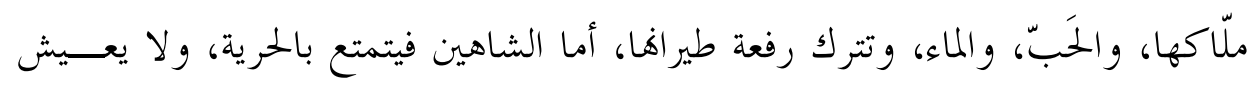
على فتات مائدة السلطان. و والماءك وترك

ودعا إقبال إلى هذا الفقر المثالي الذي لا يعني "عدم الملك، وقلة المال، ولكنه أن لا

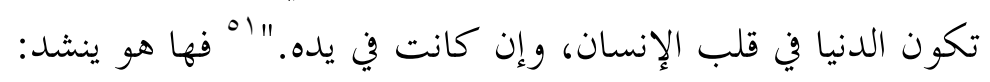

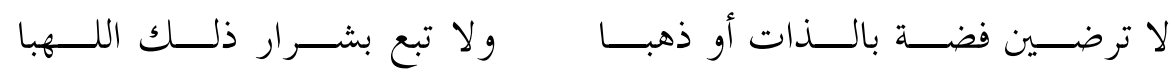

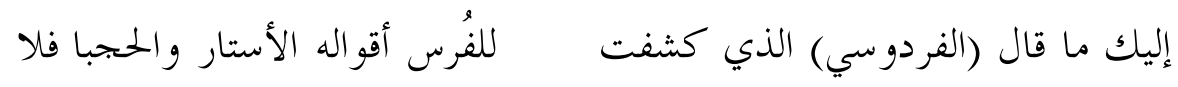

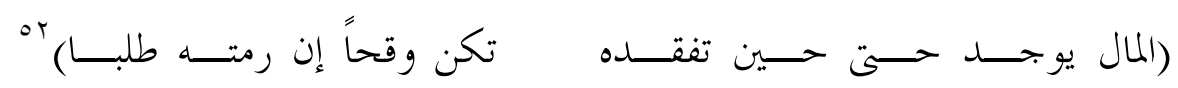

وعلى النقيض من ذلك يعتقد إقبال أن التسوّل أو التكدّي هو أكبر عائق في سبيل

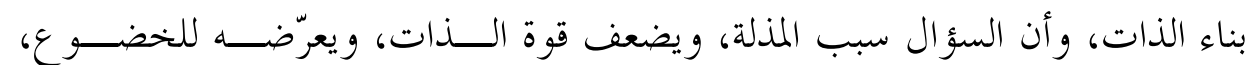

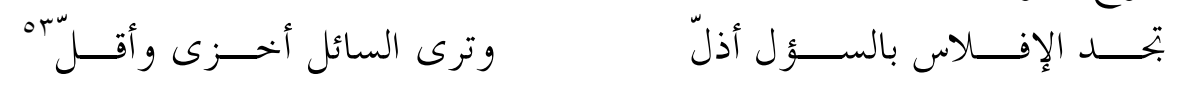
ويؤ كد أن السؤ ال يطفئ مصابيح الذات، ويقضي على جوهرها، يقول:

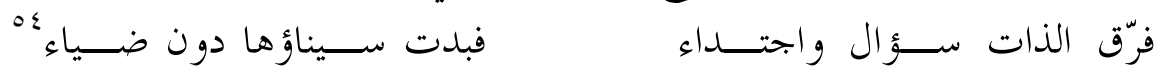

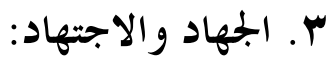

إن الجهاد والاجتهاد عنصران أساسيان لتقوية الذات، وبخاصة الذات الاجتماعية،

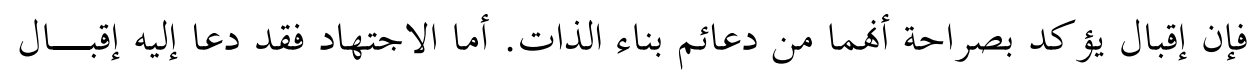

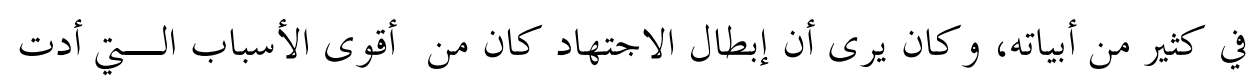

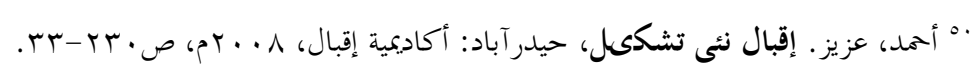

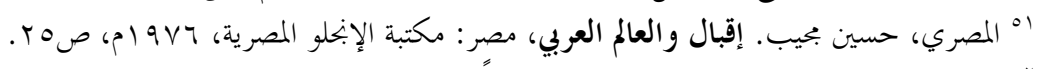

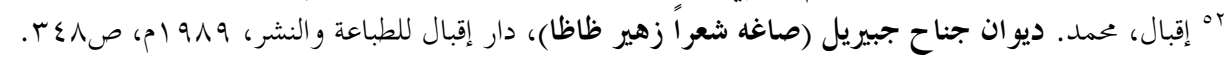

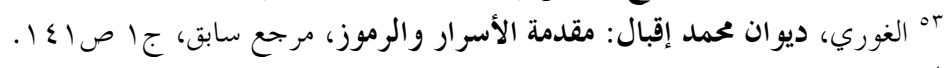

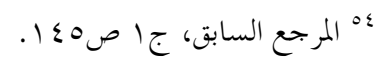


إلى ضعف المسلمين، ونعى على الذين يزعمون أن باب الاجتهاد قد أغلق، ويــــدعون

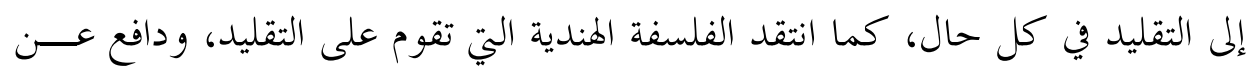

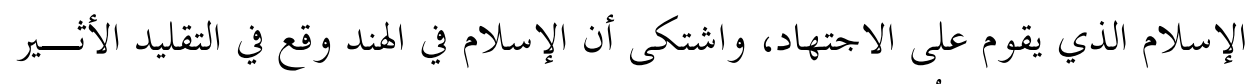

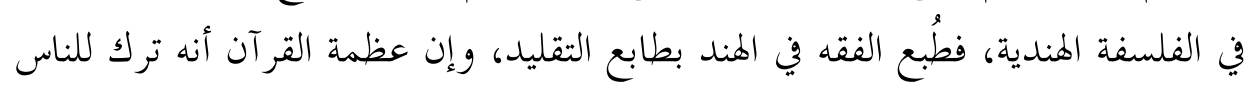

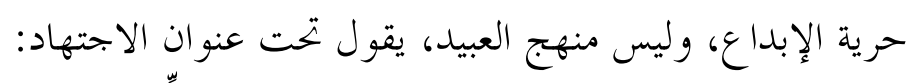

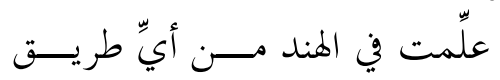

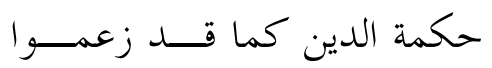

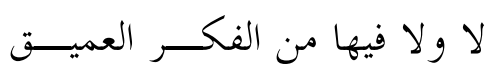

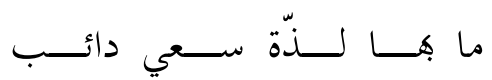

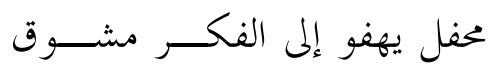

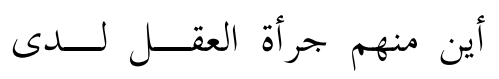

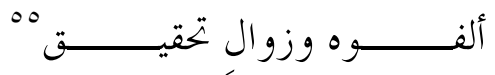

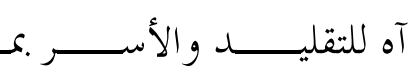

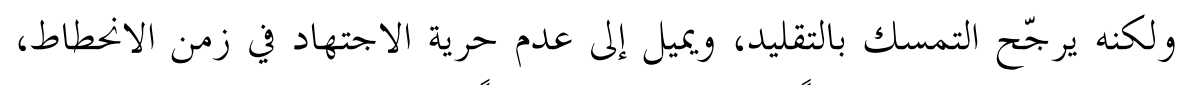

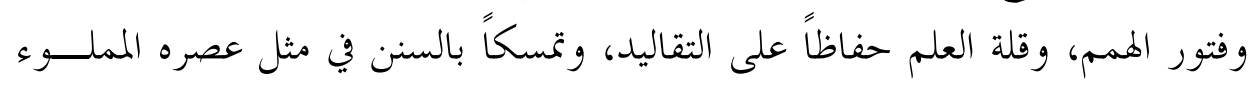

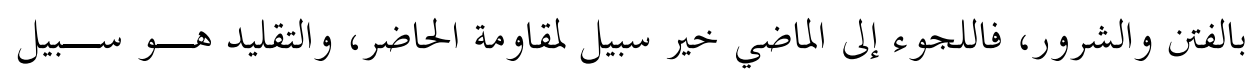
النجاة، وجمع الأمة، و الحفاظ على السنن، يقول:

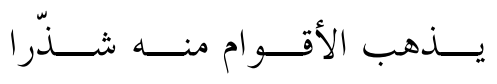

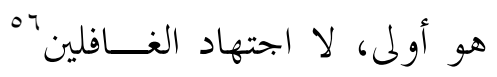

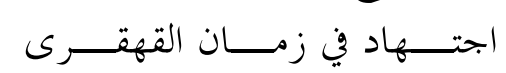

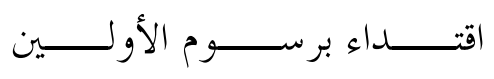

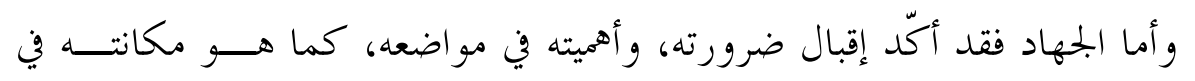

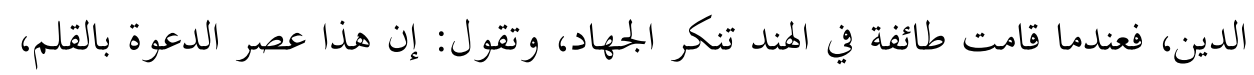

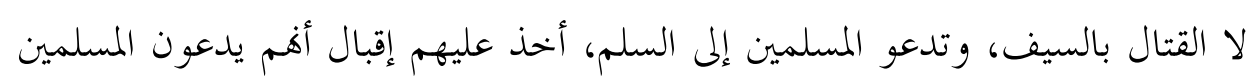

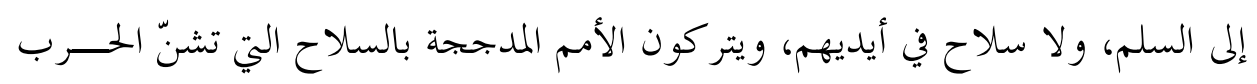

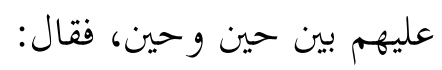

ما السيف فيه حاكم بين الأمـــم

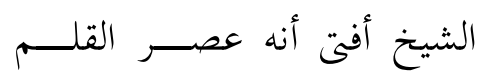
في مسجد قد صار من لغو الكلمِ؟

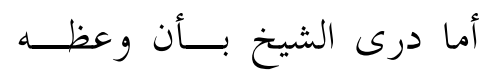

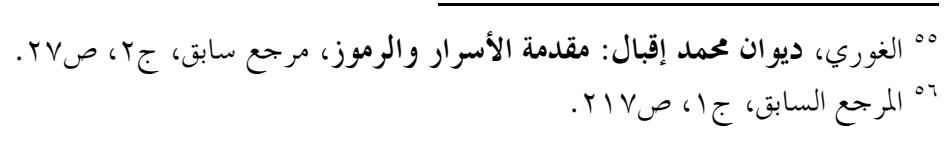




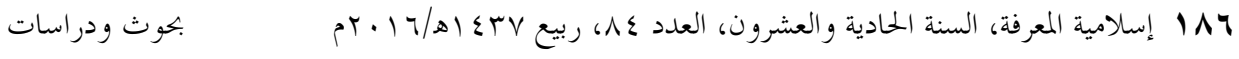

$$
\begin{aligned}
& \text { فما ترى السلاح كفُّ مســلم }
\end{aligned}
$$

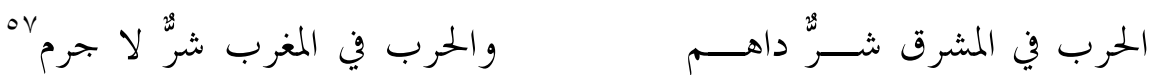

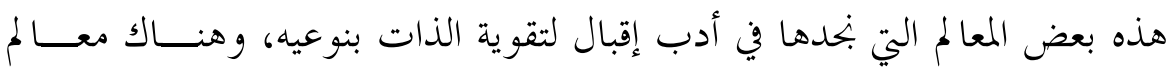

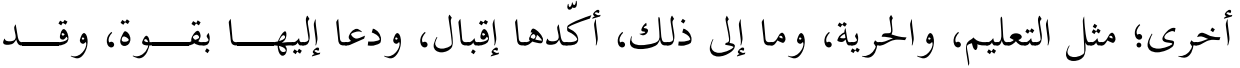
أشرت إليها في ثنايا البحث، و مطاويه.

ثالثاً: دور معرفة الذات الفرد، والذات المشتر كة في النهوض الحضاري عند إقبال

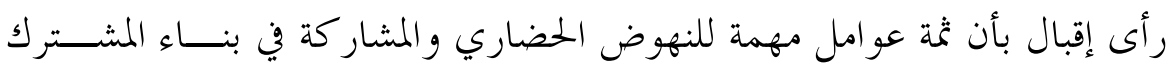

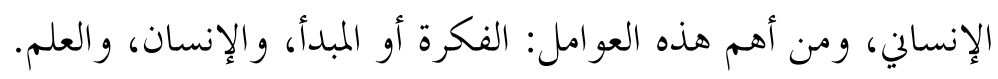

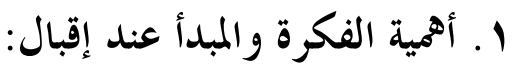

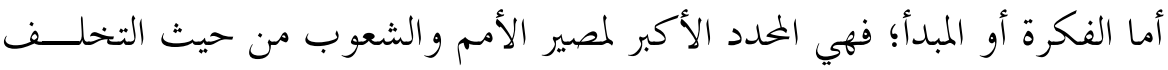

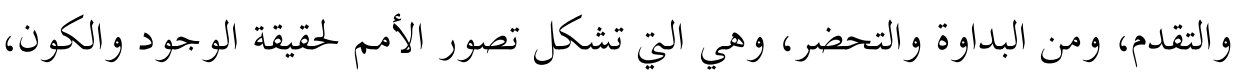

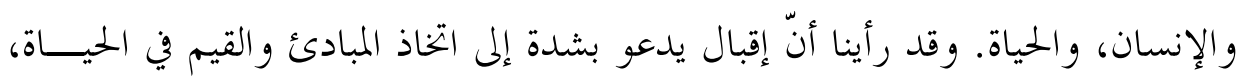

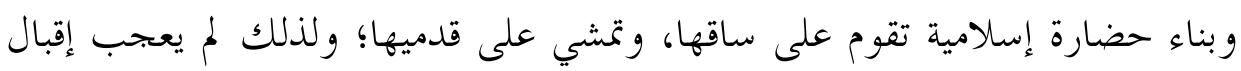

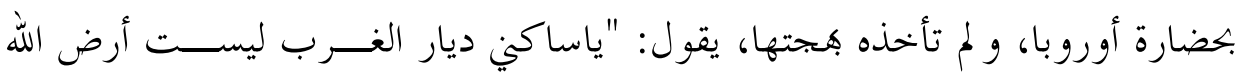

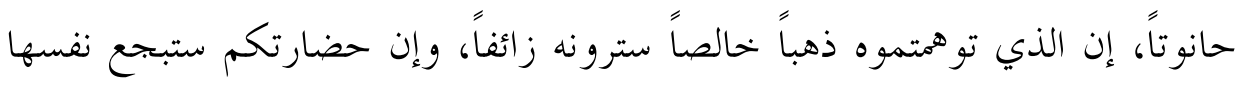

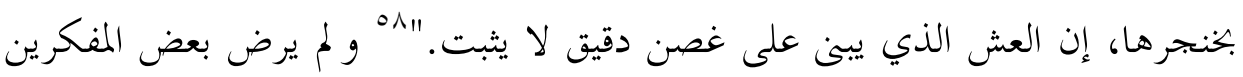

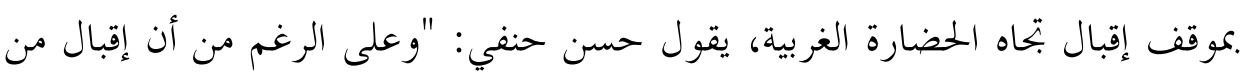

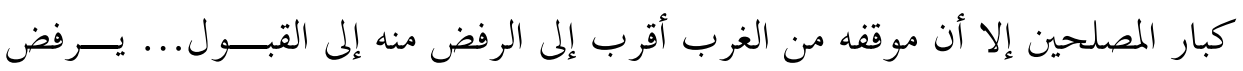

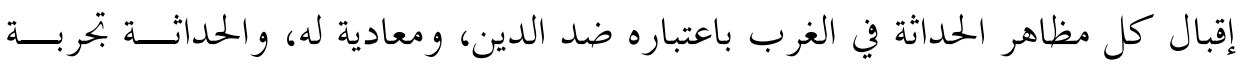

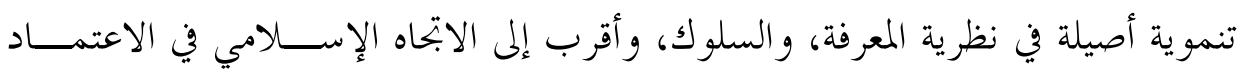
ro المرجع السابق، جr ص آب.

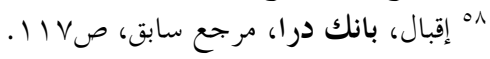


على العقل، و السيطرة على قوانين الطبيعة." "ه لكن الحقيقة أن إقبال وصل إلى هـــــا

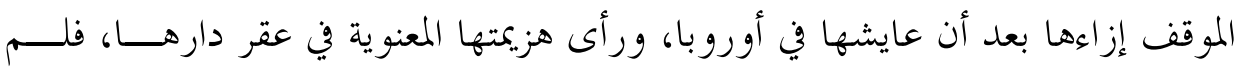

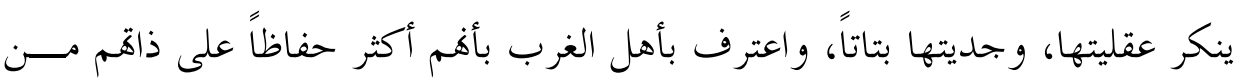
أهل الشرق، و إنما أنكر عليها إقبال إفلاسها المعنوي.

\section{Y . أهمية الإنسان عند إقبال:}

أما الإنسان فهو هدف الحضارة ووسيلتها؛ لذلك لا يتخيل وجهــود حضــارة لا

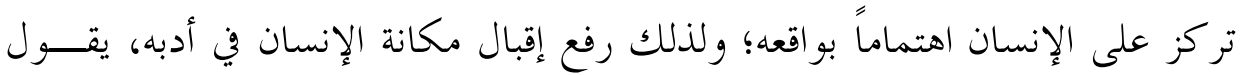

$$
\text { تحت عنوان: "روح الأرض تستقبل آدم": }
$$

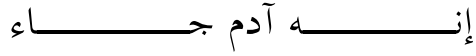

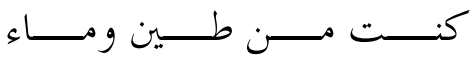
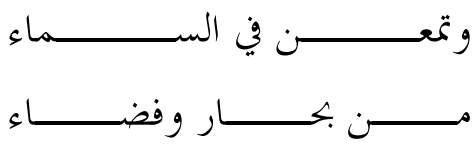

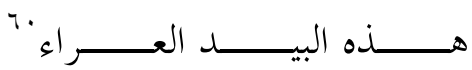

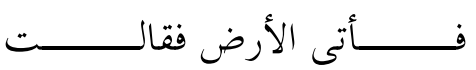

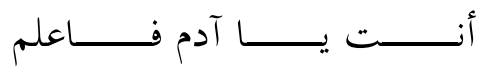

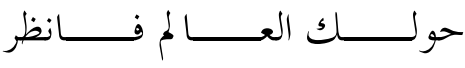

لـــك مــــا في الكــــون ملـــك

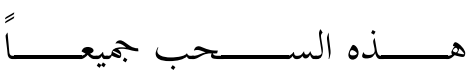

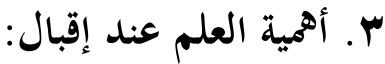

أما العلم فلا يمكن للمسلمين عند إقبال أن يستعيدوا ريادقم الحضارية إلا بــالعلم الذي يجمع بين القديم الصالح، والجلديد النافع، وبين القلب، والمـــادة، فـــدعا إقبــــال المسلمين إلى إصلاح مناهج التعليم، ونقلها من التقليد إلى الإبداع، والمدرسة من المهنة

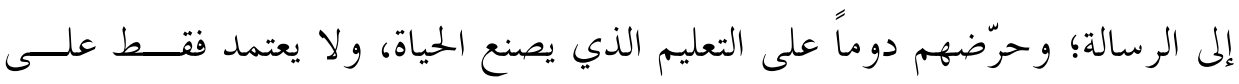

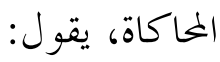




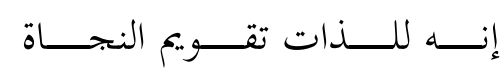

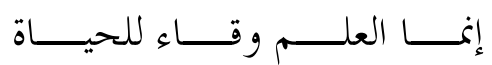

71

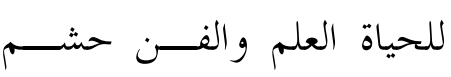

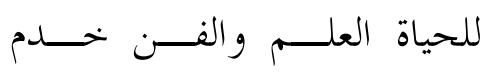

قال سمير عبد الحميد إبراهيم: "إن من أهم معالم رسالته الدعوة إلى الاعتماد على النفس، فداء الشرق عامة، و المسلمين خاصة فقدان عزة النفس، وضياع علو الهمـــة،

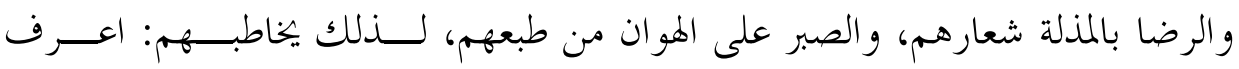

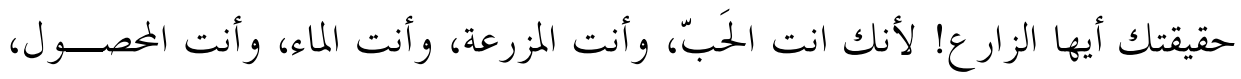

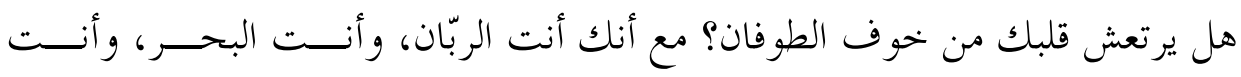

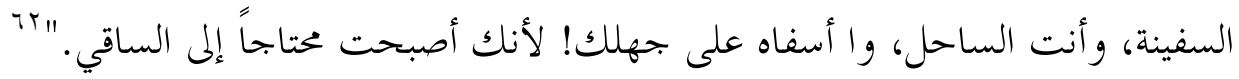
من هذا المنطلق عندما نتدارس أدب إقبال نرى أنه يؤكد ضــــرورة إيجـــاد هــــهـ الحضارة المتكاملة بعناصرها الثلاثة، وذلك بفكرته عن إثبات الذات، و ونفي الـــذات؛

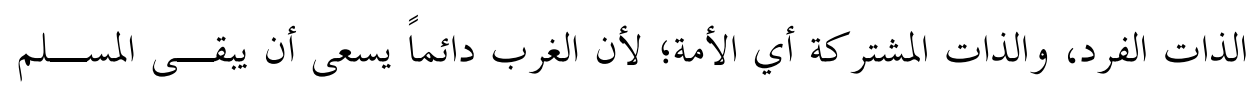

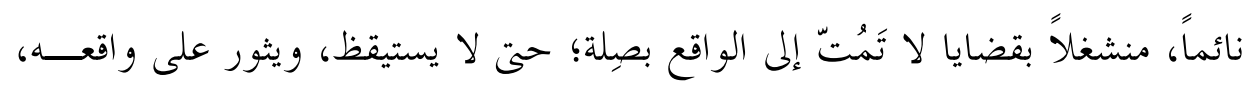

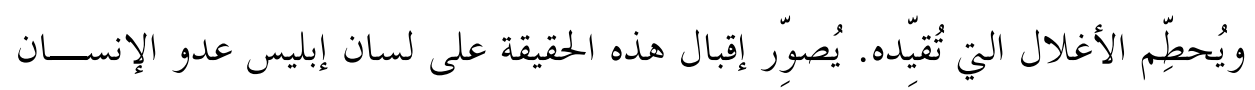
الأول؛ إذ يُخاطِب الأبالسة المؤتمرين بأمره في قصيدة برلمان إبليس من ديوانه "أرمغان

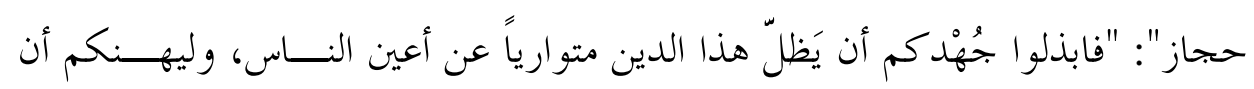

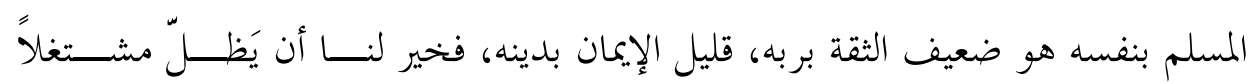

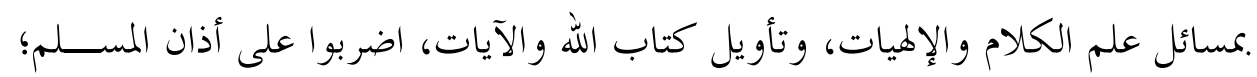

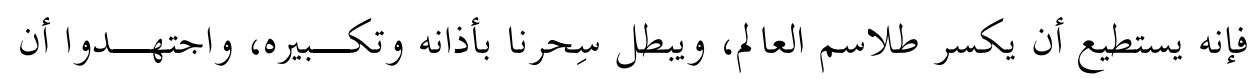
يطول ليله، ويبطئ سحره، يا شقوتنا! لو انتبهتْ هذه الأمة، التي يَعزِم عليها دينها أن

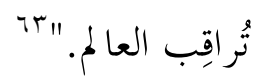

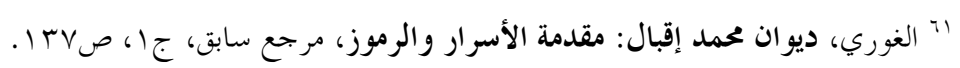

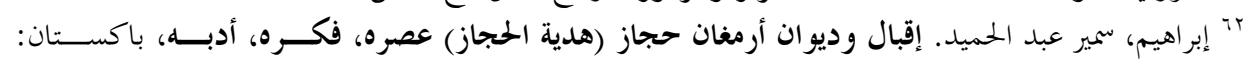

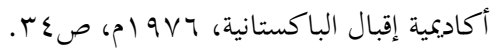

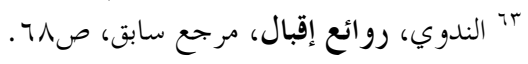




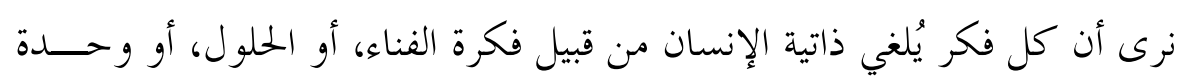

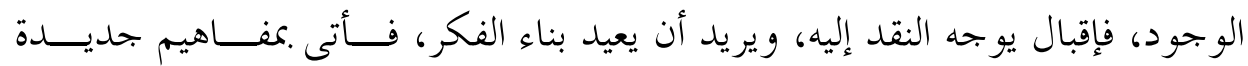

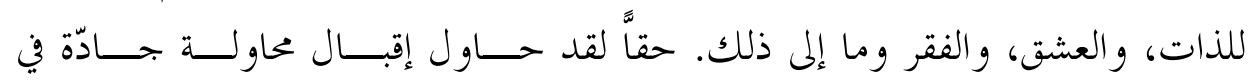

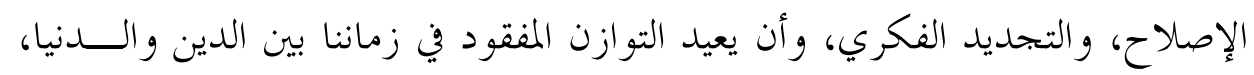

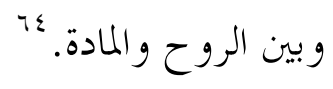

\section{ع. اعتراف كبار المفكرين بجهود إقبال في مجال النهوض الحضاري:}

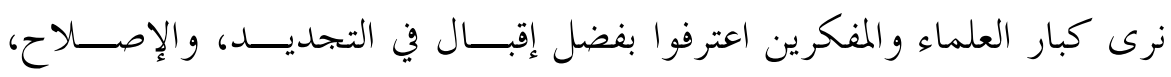
و الدعوة إلى النهوض الحضاري بابراز فكرة الذات في المسلمين، ونفخ روحها فئسيهم.

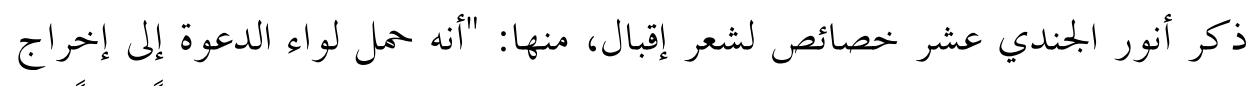

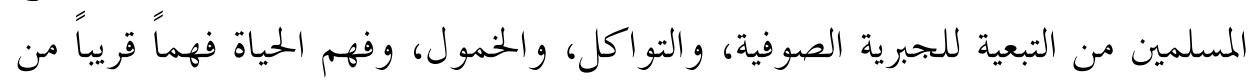

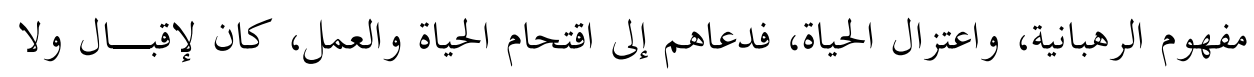

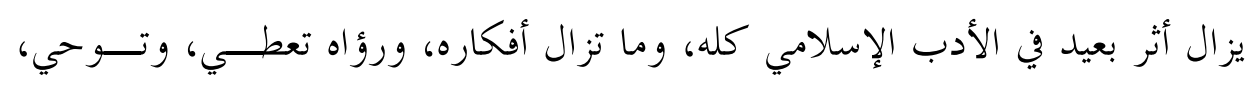

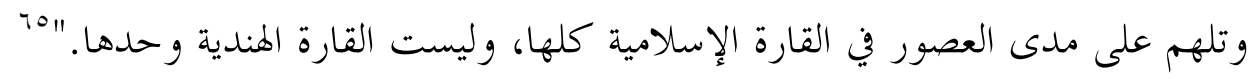

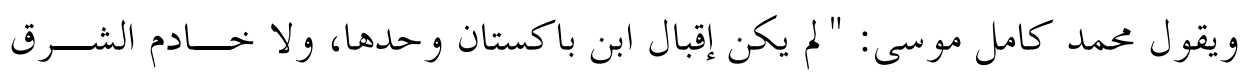

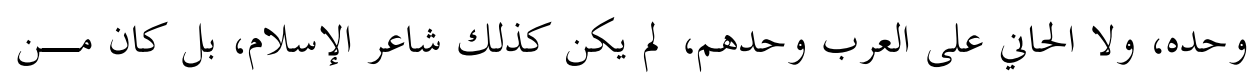

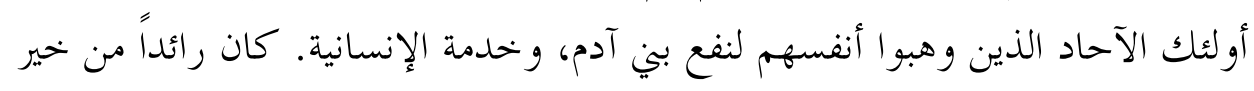

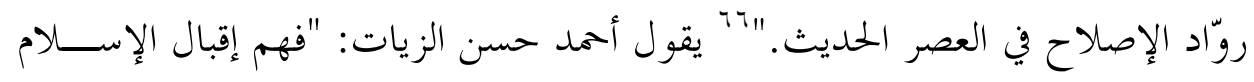

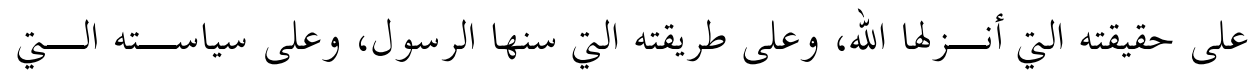

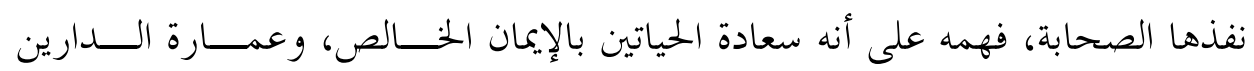

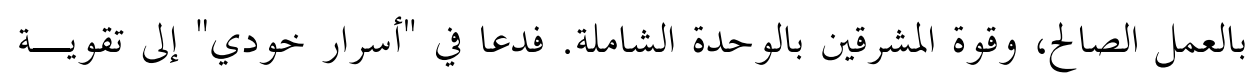

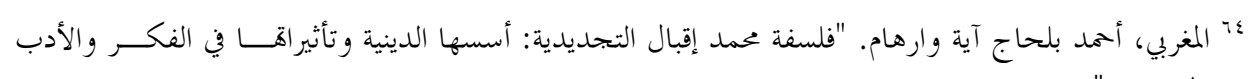

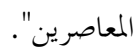

http://awabbelhaj.arabblogs.com/archive/2007/5/235923.html

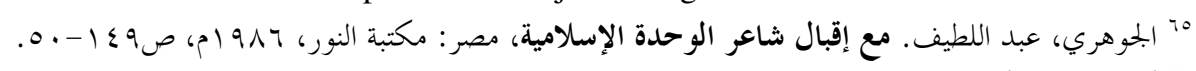

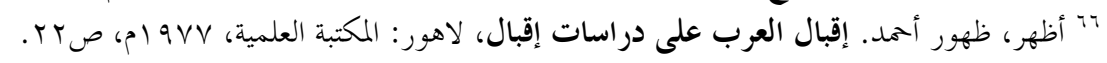




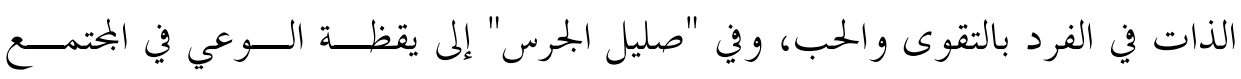

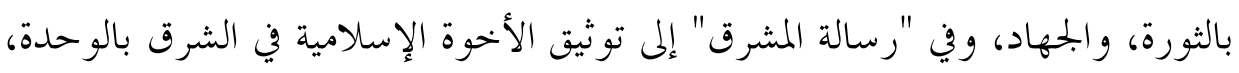
و التعاون.

ومن تم فيأبى إقبال إلا أن يختتم كتابه "بتديد الفكر الديني" بأبيات شــعرية مـــن

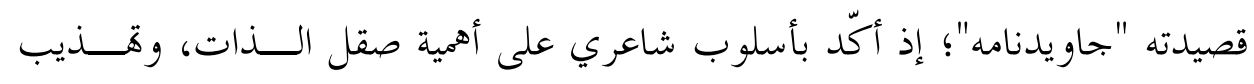
السلوك، وارتباطهما بالتجديد، يقول: ما أجلّ أن يصقل الإنسان ذاته! وأن يختبر رونقها في سطوع الشمس فاستأنف كذيب إطارك القديم وأقم كياناً جديداً

مثل هذا الكيان هو الكيان الحق وإلا فذاتك لا تزيد على أن تكون حلقة من دخانش؟ يمكن تحديد نتائج البحث فيما يأتي:

ا. إن خودي أو الذات تحمل معنيين: إيجابياً وذلك تعرف الإنســان علــى نفســه،

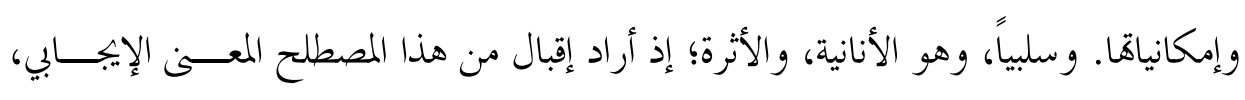

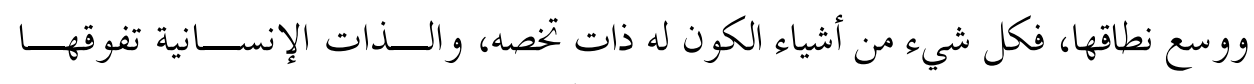

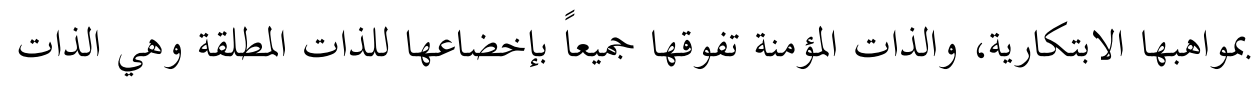


r. فكرة الذات محور فكر إقبال، وأساسه، فكل فكرة من أفكاره مرده إلى فكرة الذات.

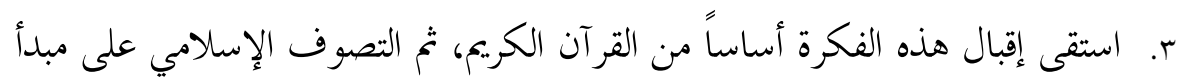

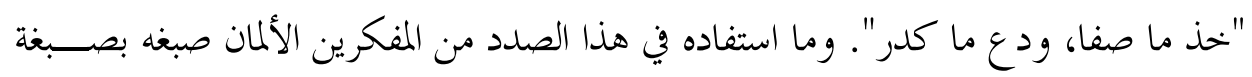
إسالامية.

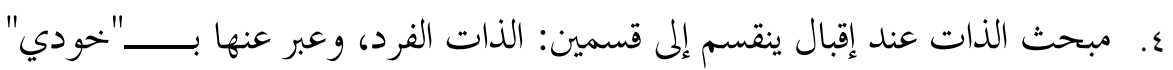
(الذات)، و الذات المشتر كة؛ أي الأمة، وعبر عنها بــبيخودي" (نفي الذات).

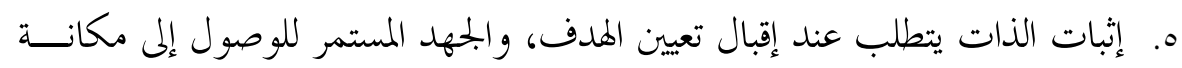
المؤمن الكامل الذي هو خليفة الله في الأرض، وهو الإنسان الكامل عنده.

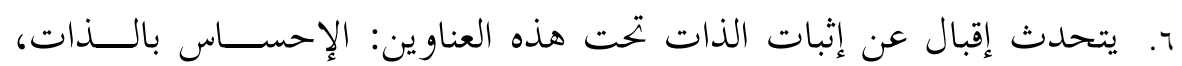

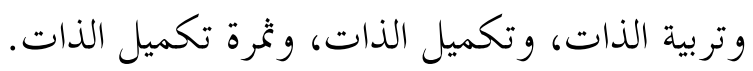
V. نفي الذات لا يعني ذوباها، وإنما يعين احترام الآخرين بتكوين بحتمع إسلامي مثالي،

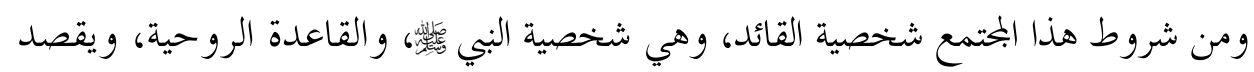

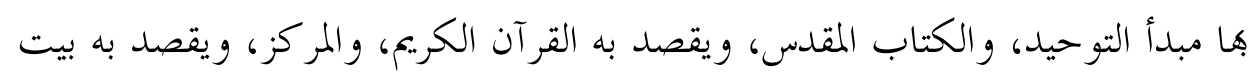
الله، و التقاليد، والأعراف، ويقصد هـا الآداب المحمدية. ومن صفات هذا البحتمع المثالي عند إقبال العبودية لله وحده، و الحرية، و العقيدة، و والقناعة.

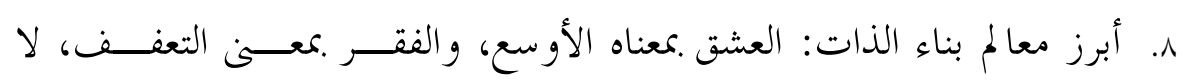
التكفف، و الجهاد، و الاجتهاد، والإبداع، والحرية، و التعليم.

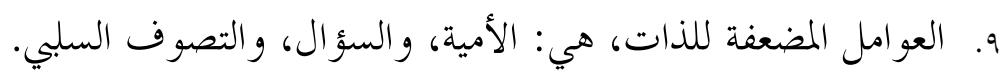

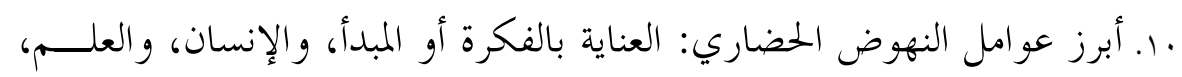

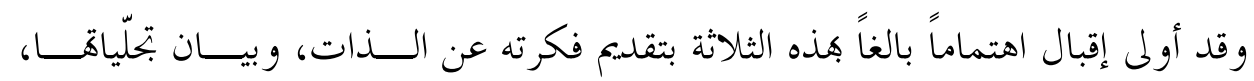
و وثمار ها.

ال. يتجلى بوضوح أن لمحمد إقبال بصمات و اضحة على المحتمع المســلم هــــهـ

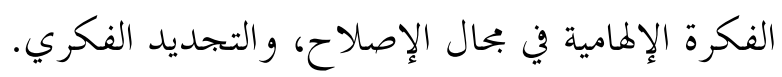

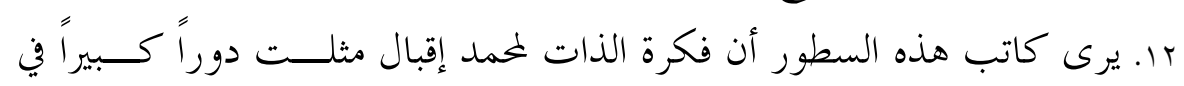


إبراز هوية المسلمين في البحال الاجتماعي، والبحال التعليمي، والبحال الدعوي بشبه القارة

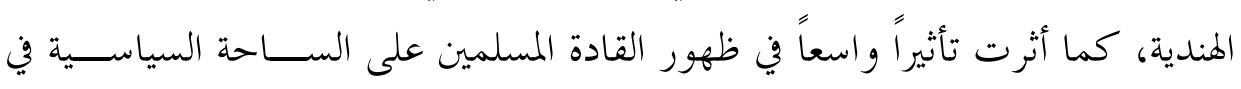

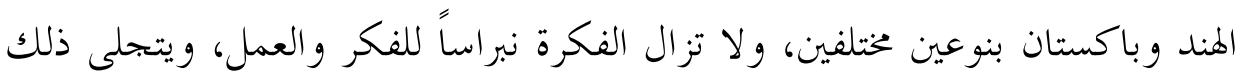
في عناية العلماء و المفكرين هها في كتاباةهم، وباحثي الماجستير والدكتوراه في أبحــاثهم الجحامعية في الهند وباكستان بصورة خحاصة، ولكن الجانب العملي التطبيقي لفكر إقبال في حياة الشعب المسلم الهندي لا يزال ضعيفاً، فليس مستو اه الديني و العلمي و الفكري

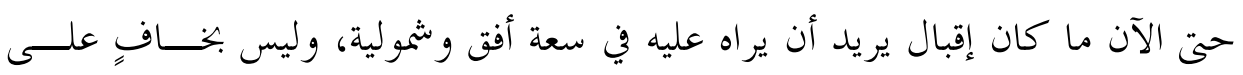
مثقف أن المفكرين والعقلانيين المعاصرين على المستوى العالمي ليسوا في غنى عن فكرة

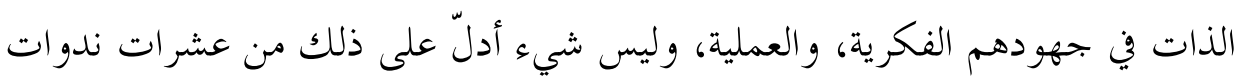

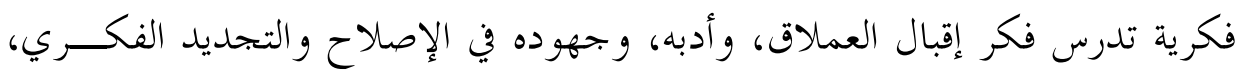
إذن ففكرة الذات بالتصور الإقبالي نابضة بالحيوية، وهي ذات صلة وثيقة Relevant بكيان المسلمين، ومستقبل أيامهم، كما أها مزدهرة حتى في عصر العولمة. ولعل الوقت مناسب لرد الاعتبار إلى إقبال وفكره من خلال:

ا. جمع أبيات "الذات" لفظاً أو دلالة في بحموعة مستقلة، وإدخحالها في مقـــررات الفلسفة والآداب بالمدارس في مراحل مختلفة. r. دراسة فلسفة الذات عند إقبال من منابعها الأصلية. r. دراستها دراسة مقارنة مع فلسفات المفكرين الغربيين عن الذات.

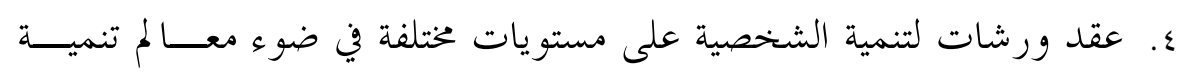
الذات، ومقوماها عند هذا الشاعر الفذّ عحمد إقبال. 